\title{
Quality Change of Mine Soils From Different Sources in Response to Amendments - A Laboratory Study
}

\author{
Ruiqiang Liu $^{1} \&$ Rattan Lal $^{1}$ \\ ${ }^{1}$ Carbon Management \& Sequestration Center, School of Environment \& Natural Resources, The Ohio State \\ University, Columbus, Ohio, USA \\ Correspondence: Ruiqiang Liu, 210 Kottman Hall, 2021 Coffey Road, the Ohio State University, Columbus, \\ Ohio 43210, USA. Tel: 1-614-292-5678. Fax: 1-614-292-7432. E-mail: liu.603@osu.edu
}

$\begin{array}{ll}\text { Received: February 6, } 2014 & \text { Accepted: March 5, } 2014 \quad \text { Online Published: March 13, } 2014 \\ \text { doi:10.5539/enrr.v4n2p20 } & \text { URL: http://dx.doi.org/10.5539/enrr.v4n2p20 }\end{array}$

\begin{abstract}
The desired vegetation is often difficult to establish in mine soils without proper amendments. In this paper, two coal-mine soils were studied to assess changes of soil quality in response to a range of amendments. Sample A with relatively neutral $\mathrm{pH}$ (6.1) was obtained from the top soil at a reclaimed surface-coal-mining site while the other sample B ( $\mathrm{pH} 4.4$ ) from nearby piles of coarse coal refuse. Amendments included zeolite of two grain sizes, flue gas desulfurization gypsum (FGD), flyash, and biosolids at $10 \%(\mathrm{w} / \mathrm{w})$ rates. Chemical analysis showed that neither soil contained significant amounts of toxic elements except for B and Sr. Lettuce seed germination indicated that original sample A possessed a better quality with $76.7 \%$ germination and $7.3 \mathrm{~cm}$ shoot length in comparison with soil B having $60 \%$ germination and $3.7 \mathrm{~cm}$ shoot length. FGD increased the $\mathrm{pH}$ of both soils from 6.1 to $>8.0$ and from 4.4 to $>6.0$, respectively. Moreover, FGD significantly enhanced lettuce germination $(83.3 \%)$ and seedling growth $(6.7 \mathrm{~cm})$ in soil B but did not greatly affect those in soil A. We concluded that soil acidity might be the major chemical constraint inhibiting plant establishment in acidic mine soils and that amendments such as FGD which could increase soil $\mathrm{pH}$ up to the neutral level would enhance plant growth in these soils. Biosolids enhanced aggregate stability of both soils with geometric mean diameter increased from antecedent values of $0.90-0.97 \mathrm{~mm}$ to $1.2-1.6 \mathrm{~mm}$. Zeolites or flyash did not significantly impact the mine soil quality.
\end{abstract}

Keywords: mine soil, reclamation, amendment, zeolite, flyash, biosolids, flue gas desulfurization gypsum (FGD)

\section{Introduction}

\subsection{Mine Soil}

Amine soil material is a structureless agglomeration of fragmented rock, subsoil, and soil that is often less weathered than the original soil profiles that it has replaced (Angel et al., 2008). Minesoils are formed on landscapes altered by mining processes, particularly by the surface mining operations: The original soil profiles have been disrupted to a depth of at least $1 \mathrm{~m}$, and sometimes partially or completely replaced by earth materials from depths below $1 \mathrm{~m}$ (Sencindiver \& Ammons, 2000). Upon exposure to the surface environment, accelerated weathering may develop soils whose properties differ greatly from the original. The type of parent material and rate of weathering are very important in the development and differentiation of soil properties. Mine soils are classified as either Entiols or Inceptisols (Angel et al., 2008; Sencindiver \& Ammons, 2000), and are either without natural genetic horizons or with only weak or moderate development (Soil Survey Staff, 1999). After passage of the Surface Mining Control and Reclamation Act (SMCRA) of 1977, mining companies are required to store the original topsoil during the coal mining phase and then return the original topsoil back to the site after the mining is completed. These types of mine soils are highly weathered, contain no acid-producing minerals, often have normal $\mathrm{pH}$ values, and thus have relatively good soil quality. Soil compaction or shallow soil depth is often an issue to a satisfactory plant (especially trees) establishment in these mine soils.

Mine soils also include ore waste and coal refuse. Coal refuse is regarded as the low-grade coal material extracted along with the coal ore. The former is separated from the latter through coal processing and then discarded. The refuse is usually composed of rock fragments derived from interseam shale or siltstone partings and waste rock materials from above or below the seam. The refuse shares many properties with the associated 
coal seam and still contains a certain amount of coal (or energy). Considering a 30\% refuse generation rate and 1094.3 million tons of coal production in USA (National Mining Association, 2012) in 2011, an estimated 328.3 million tons of coal refuse may have been generated in that year alone. Besides occupying lands for its disposal, the potential hazards of improperly reclaimed refuse include: contamination of surface and groundwater by acidic leachates and runoff, erosion and sedimentation into nearby water bodies, spontaneous combustion, and damage from landslides (Daniels \& Stewart, 2000; Daniels et al., 2010).

\subsection{Mine Soil Reclamation}

Proper reclamation of mine soils not only benefits the local environment but also contributes to offsetting the $\mathrm{CO}_{2}$ emission from industrial activities by storing carbon (C) in vegetation (e.g., Lal \& Bruce, 1999; Nabuurs et al., 2000). In comparison with agricultural soils, mine soils possess a higher $\mathrm{C}$ sink capacity. Intensively cultivated soils using recommended management practices contain levels of soil organic matter (SOM) near the C saturation state and thus have relatively low soil organic carbon (SOC) deficit, it's difficult to greatly further increase the $\mathrm{C}$ content in those soils. In contrast, drastically disturbed mine soils usually contain low SOC concentration and thus have a higher capacity for additional $\mathrm{C}$ storage as SOM. Taking advantage of the available $\mathrm{C}$ sink capacity by re-vegetation of minelands would lead to additional sequestration of atmospheric $\mathrm{CO}_{2}$. The potential for sequestration of carbon (C) in reclaimed mine soils through re-vegetation is high and merits serious consideration as one of the effective and cheap options to reduce the trend of increase in atmospheric $\mathrm{CO}_{2}$ concentration. Further, growing cellulosic crops on marginal lands, including mine soils, is being increasingly accepted as a sustainable alternative to food-crop-based bioenegy production (Tilman et al., 2006; Gelfand et al., 2013) without risks of competing for fertile agricultural lands or damaging the environment. Overall, C sequestration and bioenergy production have created a new concept of mine soil reclamation favoring both sustainable development and environmental protection.

\subsection{Mine Soil Amendments}

Effective $\mathrm{C}$ storage and biofuel production require a satisfactory soil quality so that vegetation can be easily established and maintained for a long period (e.g., 50 years) with limited management. Moreover, establishment of a vigorous plant community on a closed mining site can reduce, if not completely eliminate, the adverse effects on the surrounding environment. However, mine soils usually have poor quality including low SOM content, low $\mathrm{N}$ and $\mathrm{P}$ availability, low plant-available-water holding capacity, micronutrient imbalances or toxicity, high soil compaction, high salt concentrations, and extreme $\mathrm{pH}$ values (Daniels \& Stewart, 2000; Daniels et al., 2010). These characteristics result in unfavorable conditions for both SOC sequestration and for biofuel production. Therefore, use of soil amendments and adoption of proper management are often needed to improve physical, chemical and biological quality of the disturbed sites in order to establish vigorous vegetation and effective atmospheric $\mathrm{CO}_{2}$ sinks. A number of amendments have been tried to increase the mine soil quality for establishing a vigorous vegetation cover for mine soil reclamation, enhancing $\mathrm{C}$ sequestration, and producing biofuel feedstock. For example, manure, compost, biosolids, paper-mill sludge, and sawdust have been successfully applied to increase the SOM content and improve the physical and chemical properties of diverse mine soils (Daniels \& Haering, 1994; Li \& Daniels, 1997; Coyne et al., 1998; Roberts et al., 1988; Haering et al., 2000; Bendfeldt et al., 2001; Tompson et al., 2001; Larney et al., 2005; Forsberg \& Ledin, 2006; Shipitalo \& Bonta, 2008; Shrestha et al., 2009). Limestone and coal combustion byproducts (fly-ash, bottom ash, and flue gas desulfurization gypsum, FGD) have been widely used and extensively researched for reducing mine soil acidity (Bhumbla et al., 2000; Dick et al., 2000; Daniels et al., 2002; Shukla et al., 2005; DeSutter et al., 2014). A range of commercial $\mathrm{N}, \mathrm{P}$, and $\mathrm{K}$ fertilizers have also been used to provide effective and sufficient nutrient contents for vegetation establishment on mine lands (Daniels \& Stewart, 2000; Bendfeldt et al., 2001; Larney et al., 2005; Jacinthe \& Lal, 2007; Shrestha et al., 2009).

However, due to a wide variation in properties, different mine soils may respond differently to the same amendment in the context of soil quality improvement. Thus, an amendment which may enhance vegetation establishment in one mine soil may not do so in another. For example, FGD is effective in neutralizing soil acidity and reducing phytotoxicity of $\mathrm{Al}$ and $\mathrm{Mn}$ in acidic mine soils. However, raising soil $\mathrm{pH}$ to $>8$ is generally detrimental to plant growth when a significant amount of FGD is applied to neutral or alkaline mine soils (Clark et al., 2001). Daniel et al. (1994) suggested using high rates (300 $\left.\mathrm{Mg} \mathrm{ha}^{-1}\right)$ of biosolids coupled with heavy lime application $\left(100 \mathrm{Mg} \mathrm{ha}^{-1}\right)$ to stabilize and re-vegetate extremely acidic $(\mathrm{pH}<4)$ and metalliferous $\mathrm{Pb} / \mathrm{Zn}$ smelter wastes, but using lower rates $\left(75-150 \mathrm{Mg} \mathrm{ha}^{-1}\right)$ of biosolid alone to re-vegetate non-acidic coal refuse materials. Because of the high water soluble heavy metal contents of the smelter wastes, sufficient amount of additional lime was needed to maintain the $\mathrm{pH}$ at 7.5 or above over multiple years for a successful long-term site stabilization (Daniel et al., 1994). Therefore, determining whether a soil amendment is needed or selecting a best 
amendment material or amendment combination for mine soil re-vegetation should be based on specific mine soil properties (i.e., soil $\mathrm{pH}$ or hazardous element content).

Therefore, the principal objective of this study was to identify techniques to establish vigorous vegetation for $\mathrm{C}$ sequestration in reclaimed coal mining sites of southeastern Ohio where there was either no prior vegetation cover or the vegetation was poorly established. A laboratory study was initiated to evaluate how the specific mine soils responded to selected amendment materials for mine soil quality improvement and for satisfactory vegetation establishment, and then to identify a best amendment material or a treatment method for these specific mine soils.

The specific objectives of this study were to:

1) examine chemical compositions of two mine soils from different sources;

2) study the effects of selected amendments (zeolite of two sizes, fly-ash, FGD, and biosolids) on elemental contents in soil solutions;

3) test the effects of selected amendments on increasing mine soil $\mathrm{pH}$;

4) assess the effects of selected amendments on lettuce (Lactuca sativa L.)seed germination rate and shoot elongation in mine soil solutions;

5) evaluate the influences of selected amendments on mine soil physical properties such as aggregate stability and water holding capacity; and

6) determine how different mine soils respond to soil amendments differently in term of soil quality improvement.

\section{Materials and Methods}

\subsection{Mine Soil Sampling}

Two mine soil samples from different sources were analyzed in this study. One (soil A) was obtained from a reclaimed surface-coal-mining site (part of Hellbender Bluff Park, 40 $42^{\prime} 42^{\prime \prime} \mathrm{N}, 80^{\circ} 39^{\prime} 13^{\prime \prime} \mathrm{W}$ ), located in Madison Township between cities of Lisbon and East Liverpool, Ohio. The general soil type in that area belongs to loamy-skeletal, mixed, active, mesic Typic Hapludalfs (USDA \& NRCS, 2007). The 120-hacoal mining area was reclaimed about 40 years ago (in 1970s) after the strip-mining operations ended. The reclamation process involved replacing all of the earth material that was displaced during the mining operation and restoring the land mostly to its original contour. The established vegetation was volunteer grasses or shrubs. The other sample (soil B) was taken from coarse coal refuse piles found in a reclaimed-forest land near the city of Lisbon $\left(40^{\circ} 46^{\prime} 26^{\prime \prime} \mathrm{N}\right.$, $80^{\circ} 46^{\prime} 3^{\prime \prime} \mathrm{W}$ ), Columbiana County, Ohio. These piles were around 90-100 years old (pers. comm.). The prevailing rocks nearest to the surface are of the Pennsylvania formations consisting of shales, limestone, and sandstone, with intermingled layers of coal and commercially important clays (http://www.columbianacounty.org).

Large bulk samples $(\sim 5 \mathrm{~kg})$ were obtained by compositing several subsamples obtained at random from the surface (upper $10 \mathrm{~cm}$ ) of the land (soil A) or of each pile (soil B) in the year of 2011. The samples were then transported to the laboratory at Ohio State University where they were air-dried, gently crushed to pass a $2 \mathrm{~mm}$ sieve, and then stored pending analyses and experimental tests.

\subsection{Analyses of Mine Soils and Amendment Materials}

Soil texture was measured by the hydrometer method (Gee \& Bauder, 1986). Color of the moist soils was evaluated using Munsell notion system (Torrent \& Barrón, 1993). pH and EC of the soils and amendment materials were measured in 1:4 (solid weight : DI water weight) soil solutions (Thomas, 1996). This ratio was identical to the soil solution ratio used for later chemical analysis and germination tests so that the $\mathrm{pH}$ values obtained could be applied to these soil elutriates (Bowers et al., 1997). Total elements in the solids (soils and amendments) were analyzed using ICP spectrophotometer (Teledyne Leeman Labs) after the samples were digested in hydrofluoric acid / perchloricacid (Soltanpour et al., 1996). Concentrations of soil C and N were measured using the dry combustion method by Vario Max C/N analyzer (Elementar Americas, Inc.) (Nelson \& Sommers, 1996; Bremner, 1996). Water-stability of soil aggregates was tested and calculated by the method of Kemper and Rosenau (1986). Soil water-holding capacity (WHC) including saturated water content, field capacity, and permanent wilting point were estimated following Cassel and Nielsen (1986) at soil water potential of $0 \mathrm{MPa},-0.03 \mathrm{MPa}$, and $-1.5 \mathrm{MPa}$, respectively, after the samples were statured with tap water for $12 \mathrm{~h}$. Plant-available water holding capacity (PAWHC) was approximated by the difference between soil field capacity and permanent wilting point. This test was to assess the impact of the amendments on mine soil WHC. 


\subsection{Soil Amendment Test}

Samples were treated with five amendment materials: i) coarse zeolite with a grain size of $0.4 \sim 1.4 \mathrm{~mm}$, ii) fine zeolite with a grain size $<0.04 \mathrm{~mm}$, iii) FGD, iv) flyash, and v) biosolids. These amendments were mixed at a ratio of $10 \%$ by weight. Deionized (DI) water was added to each mixture to attain the field moisture capacity, and each amendment was tested in triplicate. Samples of the mixtures (about $100 \mathrm{~g}$ ) were taken periodically over 35 day period for $\mathrm{pH}$ measurements to determine how long it would take an amendment to improve soil $\mathrm{pH}$ and attain the reaction equilibrium. After 35-days, all the remaining samples were air dried and stored pending elemental analyses, germination tests, and physical properties measurements.

\subsection{Soil Elutriate Preparation and Analysis}

An aqueous elutriate was prepared from each composited soil sample using a 1:4 $\left(\mathrm{w} \mathrm{w}^{-1}\right)$ mixture of soil and DI water according to the method by Bowers et al. (1997). Soil mixtures were constantly mixed for a minimum of 1 $\mathrm{h}$ on an automatic shaker, followed by a $1 \mathrm{~h}$ settling period, and filtration through a $0.45 \mu \mathrm{m}$ Millipore filter. Aqueous elutriates were used for subsequent germination test and elemental analysis.

\subsection{Lettuce Seed Germination Test}

The phytotoxicity of soil elutriates was estimated using $5 \mathrm{~d}$ seed germination test (Bowers et al., 1997). Tests were conducted using butter-crunch lettuce seeds obtained from a local nursery (Columbus, Ohio, USA). Test seeds were selected for uniform size and color after screening with a \#20 sieve to remove the small seeds. Seed germination tests were prepared by placing 10 test seeds in $10 \mathrm{ml}$ of prepared elutriate contained in clear, polystyrene Petri dishes $(9 \times 50 \mathrm{~mm})$ with leak-proof covers. Three replicates of 10 seeds each were prepared for each elutriate sample. Tests were initiated within $24 \mathrm{~h}$ of preparation of the elutriate media. Control treatments (3 replicates) were prepared in a similar fashion using distilled water and potting soil as the test media, respectively. Test containers were incubated at $25^{\circ} \mathrm{C}$ under a light cycle of $18 \mathrm{~h}$ of light and $6 \mathrm{~h}$ of darkness at approximately $38 \mathrm{mEm}^{-2} \mathrm{~s}^{-1}$ for a period of $5 \mathrm{~d}$ (incubator manufactured by Percival Scientific Inc.). After $5 \mathrm{~d}$, the total number of germinated seeds was recorded and the percent germination determined for each elutriate. Germination was considered successful if the primary shoot length was equal to or greater than $3 \mathrm{~mm}$. The total length of each germinated seedlings was measured using a caliper (Bet-Art Products).

All data were statistically analyzed through one-way ANOVA using Minitab 16.1.1 (LEAD Technologies, Inc.). Treatment differences were assessed at $\mathrm{p}<0.05$.

\section{Results and Discussion}

\subsection{Chemical Compositions of Mine Soils and Amendment Materials}

The data in Table 1 show that soil A had a relatively neutral $\mathrm{pH}$ (6.14) and contained trace elements at medium levels, most of which fell within the concentration ranges in the USA soils (Kabata-Pendias \& Pendias, 1984). Moreover, this soil did not contain significant amount of salts and had a relative low EC of $23.4 \mu \mathrm{S} \mathrm{cm}{ }^{-1}$, which was also within the EC range of healthy soils $\left(<2000 \mu \mathrm{S} \mathrm{cm}^{-1}\right)$ (Bohn et al., 1979). High amount of Be (14.5 mg $\left.\mathrm{kg}^{-1}\right)$ and $\mathrm{Zn}\left(134.8 \mathrm{mg} \mathrm{kg}^{-1}\right)$ were present in this soil compared with these two element levels found in USA agricultural soils $\left(\mathrm{Be}<1.6 \mathrm{mg} \mathrm{kg}^{-1}\right.$ and $\mathrm{Zn}<25 \mathrm{mg} \mathrm{kg}^{-1}$ ) (Kabata-Pendias \& Pendias, 1984). Logan and Miller (1983) reported a range of 47 to $138 \mathrm{mg} \mathrm{kg}^{-1}$ of $\mathrm{Zn}$ in Ohio farm soils. Cox and Colvin (1996) suggested a range of 7.5 to $190 \mathrm{mg} \mathrm{kg}^{-1}$ as the background levels of $\mathrm{Zn}$ in Ohio soils and classified the soils containing 210-3, 940 $\mathrm{mg} \mathrm{kg}^{-1} \mathrm{Zn}$ as polluted by industrial wastes in this state. Thus, $\mathrm{Zn}$ content found in soil A might reflect the highest level of the background $\mathrm{Zn}$ in Ohio soils and did not indicate any contamination. However, Be level in this soil (14.5 mg kg $\mathrm{g}^{-1}$ ) was several times higher than the average background Be concentration found in normal USA soils (1.6 mg kg-1 $)$. The highest Be concentration reported in Ohio soils was $3.2 \mathrm{mg} \mathrm{kg}^{-1}$ by Cox and Colvin (1996), suggesting this coal mine soil contained concentrated element Be. Beryllium is often enriched in coals (Kabata-Pendias \& Pendias, 1984) so that it is not surprising that a coal-related mine soil contains high level of Be. Concentration of Be at15-50 times higher than the background level $\left(1 \mathrm{mg} \mathrm{kg}^{-1}\right)$ has been reported in vicinity of smelters and coal power stations (Kabata-Pendias \& Pendias, 1984). This element is known to inhibit the germination of seeds and the uptake of $\mathrm{Ca}$ and $\mathrm{Mg}$ by root and to degrade some proteins and enzymes. Relatively low Be concentrations (2-16 mg L $\left.^{-1}\right)$ in solution is highly toxic to plants. However, high concentration of $\mathrm{Be}(<$ $0.01 \mathrm{mg} \mathrm{L}^{-1}$ ) was not detected in the mine soil solution (1:4 soil to DI water ratio) in the present study (Tables 2, where the elements with concentrations below the ICP detection limits were not listed), suggesting that Be in the mine soils was strongly bound in the soil fractions and would not pose a risk to plant growth at this level (14.5 $\mathrm{mg} \mathrm{kg}^{-1}$ ). In comparison, sample B (a coal refuse) had properties more typical of mine soils such as low soil $\mathrm{pH}$ (4.37) and high sulfur (S) and C contents (Table 1). The high C content originated from the coal residual in this 
soil while the high amount of S most likely originated from the coal-mining by-products of pyrites (FeS). When exposed to the air during the coal- mining processes, the minerals were oxidized to form sulfuric acid $\left(\mathrm{H}_{2} \mathrm{SO}_{4}\right)$, acidifying the mine soils and increasing soil S content. In addition, this soil had chemical compositions similar to those of coarse coal refuse sampled in Southwest Virginia (Daniels \& Stewart, 2000), probably due to the similar geological formations. Resembling soil A, soil B also contained relatively elevated amounts of Be $\left(7.0 \mathrm{mg} \mathrm{kg}^{-1}\right)$ and $\mathrm{Zn}\left(37.8 \mathrm{mg} \mathrm{kg}^{-1}\right)$, but both lower than those in soil A. A significant high amount of $\mathrm{Sr}\left(1.67 \mathrm{~g} \mathrm{~kg}^{-1}\right)$ was found in this soil while the $\mathrm{Sr}$ level in its solution was $0.04 \mathrm{mg} \mathrm{L}^{-1}$ (Table 3), which was lower than the $4 \mathrm{mg} \mathrm{L}^{-1}$ stable $\mathrm{Sr}$ level in drinking water recommended by USEPA (ATSDR, 2004). There is no regulation on the maximum contamination level of stable $\mathrm{Sr}$ in soils but caution should be taken when using the coal refuses as growth media. The vegetation may take up and accumulate $\mathrm{Sr}$ in plant tissues which may be harmful to animals grazing on these plants. Overall, the data indicated that neither soil contained significant amount of regular toxic elements such as heavy metals, with levels close to those found in the unmined soils in the USA. Only higher levels of Be and $\mathrm{Sr}$ were found in these soils.

Table 1. Mine soil properties and contents of selected elements

\begin{tabular}{|c|c|c|c|c|c|c|}
\hline \multicolumn{2}{|l|}{ Mine soil } & Soil A & Soil B & USA soils $\dagger$ & F-test + & CV (\%) \\
\hline \multicolumn{2}{|l|}{ pH } & $6.14^{\mathrm{a}}$ & $4.37^{\mathrm{b}}$ & & $157.54^{*}$ & 1.9 \\
\hline \multicolumn{2}{|l|}{$\mathbf{E C}\left(\mu \mathrm{S} \mathrm{cm}^{-1}\right)$} & $23.4^{\mathrm{b}}$ & $43.1^{\mathrm{a}}$ & & $31.14^{*}$ & 13.6 \\
\hline \multicolumn{2}{|l|}{ Dry color } & $\begin{array}{l}2.5 \mathrm{Y} 6 / 6 \\
\text { olive yellow }\end{array}$ & $\begin{array}{l}2.5 \mathrm{Y} 4 / 0 \\
\text { dark gray }\end{array}$ & & & \\
\hline \multirow{8}{*}{$\begin{array}{l}\text { Macro- elements } \\
\qquad\left(\mathrm{g} \mathrm{kg}^{-1}\right)\end{array}$} & $\mathrm{Ca}$ & $1.84^{\mathrm{b}}$ & $1.25^{\mathrm{a}}$ & & $336.88^{*}$ & 2.5 \\
\hline & Mg & $9.55^{\mathrm{a}}$ & $2.84^{\mathrm{b}}$ & & $2898.40 *$ & 2.5 \\
\hline & $\mathbf{K}$ & $21.2^{\mathrm{b}}$ & $14.4^{\mathrm{a}}$ & & $201.22 *$ & 3.3 \\
\hline & $\mathbf{F e}$ & $51.4^{\mathrm{a}}$ & $27.6^{\mathrm{b}}$ & & $13.05^{*}$ & 9.7 \\
\hline & $\mathbf{P}$ & $0.78^{\mathrm{b}}$ & $1.34^{\mathrm{a}}$ & & $2597.44 *$ & 1.4 \\
\hline & $\mathbf{S}$ & $0.42^{\mathrm{a}}$ & $8.16^{\mathrm{a}}$ & & $8435.18^{\mathrm{ns}}$ & 2.4 \\
\hline & $\mathbf{N}$ & $1.71^{\mathrm{b}}$ & $3.14^{\mathrm{a}}$ & & $25.95^{*}$ & 14.1 \\
\hline & C & $19.1^{\mathrm{b}}$ & $105.2^{\mathrm{a}}$ & & $809.80 *$ & 6 \\
\hline \multirow{10}{*}{$\begin{array}{l}\text { Trace-elements } \\
\qquad\left(\mathrm{mg} \mathrm{kg}^{-1}\right)\end{array}$} & As & $19.1^{\mathrm{a}}$ & $23.4^{\mathrm{b}}$ & $0.1-69$ & $19.31 *$ & 5.6 \\
\hline & B & $12.2^{\mathrm{b}}$ & $26.8^{\mathrm{a}}$ & $20-55$ & $29.45^{*}$ & 16.8 \\
\hline & $\mathbf{B a}$ & $392.0^{\mathrm{b}}$ & $801.5 \mathrm{a}$ & $10-3000$ & $166.80^{*}$ & 6.5 \\
\hline & $\mathrm{Be}$ & $14.5^{\mathrm{a}}$ & $7.0^{\mathrm{b}}$ & 1.6 & $1.22 \mathrm{e} 4 *$ & $5.00 \mathrm{e}+03$ \\
\hline & $\mathbf{C u}$ & $31.8^{\mathrm{a}}$ & $17.8^{\mathrm{b}}$ & $14-29$ & $213.17 *$ & 4.7 \\
\hline & $\mathrm{Cr}$ & $25.4^{\mathrm{b}}$ & $44.4 \mathrm{a}$ & 54 & $65.64^{*}$ & 7.9 \\
\hline & $\mathbf{P b}$ & $19.8^{\mathrm{b}}$ & $63.1^{\mathrm{a}}$ & 20 & $121.96^{*}$ & 11.6 \\
\hline & Se & $5.4^{\mathrm{a}}$ & $12.2^{\mathrm{a}}$ & $<4.0$ & $14.10^{\text {ns }}$ & 22.6 \\
\hline & $\mathrm{Sr}$ & $105.1^{\mathrm{b}}$ & $1666.7^{\mathrm{a}}$ & $110-445$ & $80.76^{\mathrm{ns}}$ & 240.2 \\
\hline & $\mathrm{Zn}$ & $134.8^{\mathrm{a}}$ & $37.8^{\mathrm{b}}$ & $17-25$ & $3.79 \mathrm{e} 3 *$ & 2.2 \\
\hline
\end{tabular}

$\dagger$ Kabata-Pendias and Pendias. 1984. $\$$ Values followed by different lowercase letters in the same row are significantly different by Tukey test $(\mathrm{p}<0.05)$. ${ }^{*} \mathrm{p}<0.05$, ns: not significantly. 
Table 2. Concentrations of selected elements in 1:4 DI water solutions of soil A and mixtures of soil A and amendments

\begin{tabular}{|c|c|c|c|c|c|c|c|c|c|c|c|c|}
\hline \multirow{2}{*}{$\begin{array}{c}\text { Soil A or Soil A } \\
\text { /amendment } \\
\text { mixtures }\end{array}$} & \multicolumn{7}{|c|}{ Macro-elements $\left(\mathrm{mg} \mathrm{L}^{-1}\right)$} & \multicolumn{5}{|c|}{ Micro-elements $\left(\mathrm{mg} \mathrm{L}^{-1}\right)$} \\
\hline & $\mathbf{C a}$ & Mg & $\mathbf{K}$ & $\mathbf{S}$ & $\mathrm{Na}$ & Al & Mn & B & $\mathbf{B a}$ & $\mathrm{Cu}$ & $\mathrm{Sr}$ & $\mathbf{Z n}$ \\
\hline Mine soil A & $2.2^{\mathrm{c}}$ & $1.6^{\mathrm{c}}$ & $1.4^{\mathrm{b}}$ & $2.9^{\mathrm{c}}$ & $8.6^{\mathrm{c}}$ & $0.7^{\mathrm{a}}$ & $0.03^{\text {ns }}$ & $6.1^{\mathrm{b}}$ & $8.8 \mathrm{e}-3^{\mathrm{c}}$ & $5.6 \mathrm{e}-3^{\mathrm{b}}$ & $9.6 \mathrm{e}-3^{\mathrm{a}}$ & $2.9 \mathrm{e}-3^{\mathrm{b}}$ \\
\hline $10 \%$ coarse zeolite & $5.6^{\mathrm{c}}$ & $2.6^{\mathrm{c}}$ & $1.5^{\mathrm{b}}$ & $4.0^{\mathrm{c}}$ & $12.1^{\mathrm{b}}$ & $0.6^{\mathrm{a}}$ & $0.01^{\mathrm{ns}}$ & $6.2^{\mathrm{b}}$ & $7.2 \mathrm{e}-3^{\mathrm{c}}$ & $0.0^{\mathrm{c}}$ & $0.01^{\mathrm{c}}$ & $1.0 \mathrm{e}-3^{\mathrm{b}}$ \\
\hline $10 \%$ fine zeolite & $2.6^{\mathrm{c}}$ & $1.4^{\mathrm{c}}$ & $2.0^{\mathrm{b}}$ & $5.0^{\mathrm{c}}$ & $15.6^{\mathrm{a}}$ & $0.8^{\mathrm{a}}$ & $0.01^{\mathrm{ns}}$ & $6.6^{\mathrm{b}}$ & $6.7 \mathrm{e}-3^{\mathrm{c}}$ & $9.5 \mathrm{e}-3^{\mathrm{a}}$ & $6.6 \mathrm{e}-3^{\mathrm{d}}$ & $2.3 \mathrm{e}-3^{\mathrm{b}}$ \\
\hline $10 \%$ FGD & $131.4^{\mathrm{a}}$ & $12.1^{\mathrm{b}}$ & $4,7^{\mathrm{a}}$ & $131.0^{\mathrm{a}}$ & $9.2^{\mathrm{c}}$ & $0.2^{\mathrm{b}}$ & $0.04^{\mathrm{ns}}$ & $4.7^{\mathrm{bc}}$ & $0.07^{\mathrm{b}}$ & $0.0^{\mathrm{c}}$ & $0.18^{\mathrm{d}}$ & $3.8 \mathrm{e}-3^{\mathrm{b}}$ \\
\hline $10 \%$ flyash & $28.8^{\mathrm{b}}$ & $12.8^{\mathrm{b}}$ & $2.7^{\mathrm{ab}}$ & $38.7^{\mathrm{b}}$ & $9.4^{\mathrm{bc}}$ & $0.5^{\mathrm{a}}$ & $0.00^{\mathrm{ns}}$ & $7.8^{\mathrm{a}}$ & $0.09^{\mathrm{a}}$ & $0.0^{\mathrm{c}}$ & $0.19^{\mathrm{b}}$ & $8.1 \mathrm{e}-3^{\mathrm{b}}$ \\
\hline $10 \%$ biosolids & $42.2^{\mathrm{b}}$ & $19.5^{\mathrm{a}}$ & $1.6^{\mathrm{b}}$ & $29.6^{\mathrm{b}}$ & $5.0^{\mathrm{c}}$ & $0.2^{\mathrm{b}}$ & $0.06^{\mathrm{ns}}$ & $3.6^{\mathrm{c}}$ & $0.06^{\mathrm{b}}$ & $4.5 \mathrm{e}-3^{\mathrm{b}}$ & $0.14^{\mathrm{c}}$ & $0.13^{\mathrm{a}}$ \\
\hline $\begin{array}{c}\text { Representative } \\
\text { soils }\end{array}$ & $30-300$ & $5-50$ & $1-10$ & $50-500$ & $0.5-5$ & $<0.01$ & $0-10$ & & & $0.03-0.3$ & & $\begin{array}{c}< \\
0.005\end{array}$ \\
\hline F-test & $90.95^{*}$ & $31.74^{*}$ & $90.95^{*}$ & $117.66^{*}$ & $35.67^{*}$ & $17.88^{*}$ & $3.12^{\mathrm{ns}}$ & $15.39^{*}$ & $132.56^{*}$ & $21.18^{*}$ & $64.37^{*}$ & $5.31^{*}$ \\
\hline CV (\%) & 20.8 & 22.7 & 20.8 & 18.3 & 8.5 & 16.3 & 67.8 & 9.0 & 11.4 & 37.1 & 17.5 & 52.1 \\
\hline
\end{tabular}

$\dagger$ Bohn et al. 1979; $\$$ Values followed by different lowercase letters in the same column are significantly different by Tukey test $(\mathrm{p}<0.05){ }^{*} \mathrm{p}<0.05$, ns: not significantly.

Table 3. Concentrations of selected elements in 1:4 DI water solutions of soil B and mixtures of soil B and amendments

\begin{tabular}{|c|c|c|c|c|c|c|c|c|c|c|c|}
\hline \multirow{2}{*}{$\begin{array}{c}\text { Soil B or soil } \\
\text { B/amendment mixture }\end{array}$} & \multicolumn{7}{|c|}{ Macro-elements $\left(\mathrm{mg} \mathrm{L}^{-1}\right)$} & \multicolumn{4}{|c|}{ Micro-elements $\left(\mathrm{mg} \mathrm{L}^{-1}\right)$} \\
\hline & Ca & Mg & $\mathbf{K}$ & $\mathbf{S}$ & $\mathrm{Na}$ & Al & Mn & B & $\mathbf{B a}$ & $\mathrm{Sr}$ & $\mathbf{Z n}$ \\
\hline Mine soil B & $4.39^{\mathrm{c}}$ & $0.53^{\mathrm{d}}$ & $5.68^{\mathrm{b}}$ & $8.90^{\mathrm{c}}$ & $6.72^{\mathrm{c}}$ & $0.45^{\mathrm{b}}$ & $0.67^{\mathrm{b}}$ & $4.8^{\mathrm{bc}}$ & $0.05^{\mathrm{b}}$ & $0.04^{\mathrm{c}}$ & $0.04^{\mathrm{c}}$ \\
\hline $10 \%$ coarse zeolite & $4.80^{\mathrm{c}}$ & $0.60^{\mathrm{d}}$ & $2.84^{\mathrm{c}}$ & $10.66^{\mathrm{c}}$ & $12.11^{\mathrm{b}}$ & $0.61^{\mathrm{ab}}$ & $0.22^{\mathrm{b}}$ & $5.6^{\mathrm{b}}$ & $0.03^{\mathrm{c}}$ & $0.02^{\mathrm{c}}$ & $0.03^{\mathrm{c}}$ \\
\hline $10 \%$ fine zeolite & $3.32^{\mathrm{c}}$ & $0.51^{\mathrm{d}}$ & $4.47^{\mathrm{bc}}$ & $12.78^{\mathrm{c}}$ & $18.43^{\mathrm{a}}$ & $0.53^{\mathrm{ab}}$ & $0.33^{\mathrm{b}}$ & $5.8^{\mathrm{b}}$ & $0.00^{\mathrm{d}}$ & $0.01^{\mathrm{c}}$ & $0.02^{\mathrm{c}}$ \\
\hline $10 \%$ FGD & $133.37^{\mathrm{a}}$ & $6.98^{\mathrm{a}}$ & $10.69^{\mathrm{a}}$ & $150.32^{\mathrm{a}}$ & $7.33^{\mathrm{c}}$ & $0.19^{\mathrm{c}}$ & $0.51^{\mathrm{b}}$ & $4.3^{\mathrm{c}}$ & $0.05^{\mathrm{b}}$ & $0.26^{\mathrm{b}}$ & $0.02^{\mathrm{c}}$ \\
\hline $10 \%$ flyash & $36.78^{\mathrm{b}}$ & $3.47^{\mathrm{b}}$ & $10.28^{\mathrm{a}}$ & $48.54^{\mathrm{b}}$ & $9.50^{\mathrm{c}}$ & $0.65^{\mathrm{a}}$ & $3.53^{\mathrm{a}}$ & $8.3^{\mathrm{a}}$ & $0.08^{\mathrm{a}}$ & $0.38^{\mathrm{a}}$ & $0.12^{\mathrm{b}}$ \\
\hline $10 \%$ biosolids & $11.91^{\mathrm{c}}$ & $2.24^{\mathrm{c}}$ & $6.18^{\mathrm{b}}$ & $39.38^{\mathrm{bc}}$ & $8.92^{\mathrm{c}}$ & $0.51^{\mathrm{ab}}$ & $3.37^{\mathrm{a}}$ & $6.0^{\mathrm{b}}$ & $0.03^{\mathrm{b}}$ & $0.07^{\mathrm{c}}$ & $0.14^{\mathrm{a}}$ \\
\hline Representative soils $\uparrow$ & $30-300$ & $5-50$ & $1-10$ & $50-500$ & $0.5-5$ & $<0.01$ & $0-10$ & & $0.03-0.3$ & $<0.005$ & \\
\hline F-test: & $58.25^{*}$ & $71.90^{*}$ & $71.66^{*}$ & $53.50^{*}$ & $68.30^{*}$ & $25.36^{*}$ & $139.18^{*}$ & $25.64^{*}$ & $125.44^{*}$ & $123.13^{*}$ & 79.34 \\
\hline $\mathrm{CV}(\%)$ & 29.2 & 17.8 & 23.2 & 7.0 & 7.0 & 9.5 & 13.1 & 6.7 & 7.4 & 14.8 & 13.7 \\
\hline
\end{tabular}

$\dagger$ Values followed by different lowercase letters in the same column are significantly different by Tukey test $(\mathrm{p}<$ $0.05){ }^{*} \mathrm{p}<0.05$, ns: not Significantly 
Table 4. Amendment properties and contents of selected elements

\begin{tabular}{|c|c|c|c|c|c|c|c|c|}
\hline \multicolumn{2}{|l|}{ Amendment } & Coarse zeolite & Fine zeolite & FGD & flyash & Biosolids & F Test $\dagger$ & CV(\%) \\
\hline \multicolumn{2}{|l|}{ pH in 1:4 DI water } & $9.5^{\mathrm{b}}$ & $8.6^{\mathrm{c}}$ & $11.2^{\mathrm{a}}$ & $7.6^{\mathrm{d}}$ & $7.8^{\mathrm{d}}$ & $87.09^{*}$ & 3.1 \\
\hline \multicolumn{2}{|l|}{ EC in 1:4 DI water $\left(\mu \mathrm{S} \mathrm{cm}^{-1}\right)$} & $46.5^{\mathrm{c}}$ & $106.1^{\mathrm{c}}$ & $827^{\mathrm{b}}$ & $893^{\mathrm{b}}$ & $1763^{\mathrm{a}}$ & $241.05^{*}$ & 10.7 \\
\hline \multicolumn{2}{|l|}{ Particle size } & $1.4 \sim 0.4 \mathrm{~mm}$ & $<0.04 \mathrm{~mm}$ & $<2 \mathrm{~mm}$ & $<0.3 \mathrm{~mm}$ & lump & & \\
\hline \multirow{6}{*}{ Macro-elements $\left(\mathrm{g} \mathrm{kg}^{-1}\right)$} & $\mathrm{Ca}$ & $21.3^{\mathrm{c}}$ & $18.56^{\mathrm{c}}$ & $134.74^{\mathrm{a}}$ & $9.53^{\mathrm{c}}$ & $4.10^{\mathrm{b}}$ & $310.38^{*}$ & 11.2 \\
\hline & Mg & $6.37^{\mathrm{a}}$ & $5.11^{\mathrm{a}}$ & $4.12^{\mathrm{b}}$ & $1.59^{\mathrm{c}}$ & $6.88^{\mathrm{a}}$ & $267.61^{*}$ & 4.6 \\
\hline & $\mathbf{K}$ & $7.30^{\mathrm{a}}$ & $5.11^{\mathrm{b}}$ & $2.14^{\mathrm{d}}$ & $3.64^{\mathrm{c}}$ & $2.66^{\mathrm{d}}$ & $104.93^{*}$ & 8.5 \\
\hline & $\mathrm{Fe}$ & $9.09^{\mathrm{d}}$ & $7.90^{\mathrm{d}}$ & $20.01^{\mathrm{b}}$ & $89.22^{\mathrm{a}}$ & $13.82^{\mathrm{c}}$ & $3260.84^{*}$ & 3.7 \\
\hline & $\mathbf{P}$ & $0.16^{\mathrm{c}}$ & $0.11^{\mathrm{c}}$ & $0.20^{\mathrm{c}}$ & $1.01^{\mathrm{b}}$ & $20.00^{\mathrm{a}}$ & $22160.83^{*}$ & 2.4 \\
\hline & $\mathbf{s}$ & $0.51^{\mathrm{d}}$ & $0.49^{\mathrm{d}}$ & $84.21^{\mathrm{a}}$ & $3.04^{\mathrm{c}}$ & $14.49^{\mathrm{b}}$ & $5232.00^{*}$ & 4.2 \\
\hline \multirow{10}{*}{ Micro-elements ( $\left.\mathrm{mg} \mathrm{kg}^{-1}\right)$} & As & $4.6^{\mathrm{d}}$ & $2.7^{\mathrm{d}}$ & $34.1^{\mathrm{b}}$ & $158.3^{\mathrm{a}}$ & $9.1^{\mathrm{c}}$ & $9015.48^{*}$ & 2.9 \\
\hline & B & $0^{\mathrm{d}}$ & $0^{\mathrm{d}}$ & $188.0^{\mathrm{b}}$ & $304.3^{\mathrm{a}}$ & $34.2^{\mathrm{c}}$ & $2015.46^{*}$ & 7 \\
\hline & $\mathbf{B a}$ & $222.1^{\mathrm{b}}$ & $137.7 b^{c}$ & $88.0^{\mathrm{c}}$ & $155.6^{\mathrm{bc}}$ & $378.3^{\mathrm{a}}$ & $41.46^{*}$ & 15.4 \\
\hline & $\mathrm{Be}$ & $4.40^{\mathrm{c}}$ & $3.90^{\mathrm{c}}$ & $5.98^{\mathrm{b}}$ & $28.57^{\mathrm{a}}$ & $3.00^{\mathrm{d}}$ & $3887.34^{*}$ & 3.3 \\
\hline & Cd & $0.31^{\mathrm{d}}$ & $0.32^{\mathrm{d}}$ & $1.01^{\mathrm{c}}$ & $4.27^{\mathrm{a}}$ & $3.31^{\mathrm{b}}$ & $2146.35^{*}$ & 3.7 \\
\hline & $\mathrm{Cu}$ & $5.40^{\mathrm{d}}$ & $6.70^{\mathrm{cd}}$ & $14.58^{\mathrm{c}}$ & $63.87^{\mathrm{b}}$ & $468.90^{\mathrm{a}}$ & $11381.33^{*}$ & 2.9 \\
\hline & $\mathrm{Cr}$ & $3.10^{\mathrm{d}}$ & $4.90^{\mathrm{d}}$ & $18.12^{\mathrm{c}}$ & $75.76^{\mathrm{a}}$ & $55.30^{\mathrm{b}}$ & $358.04^{*}$ & 9.5 \\
\hline & $\mathbf{P b}$ & $31.00^{\mathrm{bc}}$ & $13.30^{\mathrm{c}}$ & $7.62^{\mathrm{c}}$ & $41.38^{\mathrm{b}}$ & $78.80^{\mathrm{a}}$ & $30.66^{*}$ & 25.7 \\
\hline & $\mathbf{S r}$ & $277^{\mathrm{b}}$ & $248.8^{\mathrm{c}}$ & $178.1^{\mathrm{d}}$ & $134.61^{\mathrm{a}}$ & $256.9^{c}$ & $209.46^{*}$ & 2.7 \\
\hline & $\mathbf{Z n}$ & $41.50^{\mathrm{c}}$ & $50.2^{\mathrm{c}}$ & $40.9^{\mathrm{c}}$ & $340.7^{\mathrm{b}}$ & $2330.5^{\mathrm{a}}$ & $20049.55^{*}$ & 2.4 \\
\hline
\end{tabular}

$\dagger$ Values followed by different lowercase letters in the same row are significantly different by Tukey test $(\mathrm{p}<$ $0.05){ }^{*} \mathrm{p}<0.05$, ns: not significantly.

Table 2 indicates that the 1:4 solution of soil A contained less amounts of $\mathrm{Ca}, \mathrm{Mg}, \mathrm{K}$, and $\mathrm{S}$ but more of $\mathrm{Al}$ and $\mathrm{Na}$ when compared with those found in the representative agricultural soil solutions (Bohn et al., 1979). The latter two elements, esp. Al, may negatively affect plant growth in this soil. In contrast, only trace levels of $\mathrm{Cu}$ and $\mathrm{Zn}$ were found in the solution, suggesting that those elements of heavy metals would not be toxic to the vegetation. Instead, they might be plant nutrients at necessary or somewhat deficient levels. Table 2 also indicates that the amendments increased the macro-nutrient levels in the soil solution, showing the beneficial role of these amendments to vegetation and soil reclamation. For example, FGD enhanced the levels of $\mathrm{Ca}, \mathrm{Mg}$, $\mathrm{K}$, and $\mathrm{S}$ of the original soil from deficit to average levels while reduced the concentration of Al. Similar effects were also observed for soils amended with flyash and biosolids. However, all amendment except the biosolids increased the $\mathrm{Na}$ concentrations in the solution, indicating application of these inorganic amendment materials in significant amounts might cause soil salinization. FGD, flyash, and biosolids apparently increased the $\mathrm{Sr}$ concentrations in the solution while $\mathrm{Zn}$ concentration was doubled in the solution of the biosolids-amended soil. The former might have been caused by significant amount of soluble Ca present in the solids (Table 4) and increased release of $\mathrm{Sr}$ from the soil by ion exchange with $\mathrm{Ca}$. The latter was due to high $\mathrm{Zn}$ contents in the biosolids (Table 4). Those data suggest possible related soil contaminations (esp. Zn) if high rate of amendments is used.

Compared with that of soil A, soil B solution contained slightly higher amounts of some important plant nutrients such as $\mathrm{Ca}, \mathrm{K}, \mathrm{S}$, and $\mathrm{Mn}$ but those were still about 10 times lower in concentrations than those present in the regular soils (Table 3), except for $\mathrm{K}$. These data suggest that the nutrient deficiency is a problem in mine soils. Higher concentrations of $\mathrm{Ba}, \mathrm{Sr}$, and $\mathrm{Zn}$ were also present in soil $\mathrm{B}$ solution but in insignificant amounts ( $0.01 \mathrm{mg} \mathrm{L}^{-1}$ ). Using zeolite did not significantly affect the solution compositions except for $\mathrm{Na}$ which increased by 2-3 times by zeolite addition. Application of FGD significantly increased the macro-nutrient ( $\mathrm{Ca}$, Ma, $\mathrm{K}$, and S) levels to within the ranges of those in the regular soils, suggesting the fertilizing effects of this amendment besides acidity neutralization. Amendments of flyash and biosolids also enhanced the macro-nutrient levels but less significantly than that of FGD. Flyash and biosolids applications increased levels of Mn and Zn (Table 3)in 
the soils as well.

There are increasing concerns on reusing solid wastes as soil amendments in the field because, depending on the sources, heavy metals might be present in flyash and biosolids in significant amounts (e.g., USEPA, 1988; Haering et al., 2000). The data in Table 4show the chemical compositions of the amendments used in this research. Generally, the natural mineral - zeolite - contained low amounts of impurities and thus had lower EC. This mineral contained relatively higher amounts of $\mathrm{Mg}$ and $\mathrm{K}$. In comparison, the industrial wastes (fly-ash, FGD, and biosolids) contained higher amounts of other nutrients (e.g., $\mathrm{Ca}, \mathrm{Fe}$, and $\mathrm{P}$ ) as well as heavy metals including $\mathrm{Cu}, \mathrm{Cr}$, and $\mathrm{Pb}$. Specifically, FGD contained the highest level of $\mathrm{Ca}$ and $\mathrm{S}$, thus being able to provide both nutrients to the plants in the soils where the $\mathrm{Ca}$ and $\mathrm{S}$ are deficient. Flyash contained the highest amounts of $\mathrm{Fe}, \mathrm{As}$, and $\mathrm{B}$ and significant amounts of $\mathrm{Cu}, \mathrm{Cr}, \mathrm{Pb}$, and $\mathrm{Zn}$. Biosolids contained the highest amount of $\mathrm{P}$ and significant amounts of $\mathrm{Fe}$ and $\mathrm{S}$ but also contained the highest amounts of $\mathrm{Zn}, \mathrm{Cu}, \mathrm{Pb}$, and significant amount of $\mathrm{Cr}$. The extremely high concentration of $\mathrm{Zn}\left(2.33 \mathrm{~g} \mathrm{~kg}^{-1}\right)$ may restrict application of this solid in the field due to the concerns of $\mathrm{Zn}$ contamination. All those industrial wastes had high EC. Data in Table 4 also indicate that all the amendments had alkaline $\mathrm{pH}$ values ranging from 7.6-11.2, showing their capacity to neutralize mine soil acidity and increase soil $\mathrm{pH}$.

\subsection{Mine Soil pH Changes With Amendments}

Figure 1 shows that application of FGD amendment prominently increased the mine soil $\mathrm{pH}$ through the $\sim 30-\mathrm{d}$ incubation period when $\mathrm{pH}$ of soil A was enhanced from 6.14 to above 8.10 (Figure 1a) while that of soil B was amended from 4.37 to $>6.00$ (Figure $1 \mathrm{~b}$ ). The highest neutralization capacity of this material arose from the remaining strong alkaline $\mathrm{CaO}$ and $\mathrm{Ca}(\mathrm{OH})_{2}$ in the FGD product (Crews \& Dick, 1998; Clark et al., 2001; Kost et al., 2005), which was also reflected by the highest $\mathrm{pH}$ value of this material $(\mathrm{pH}=11.2$, Table 4).
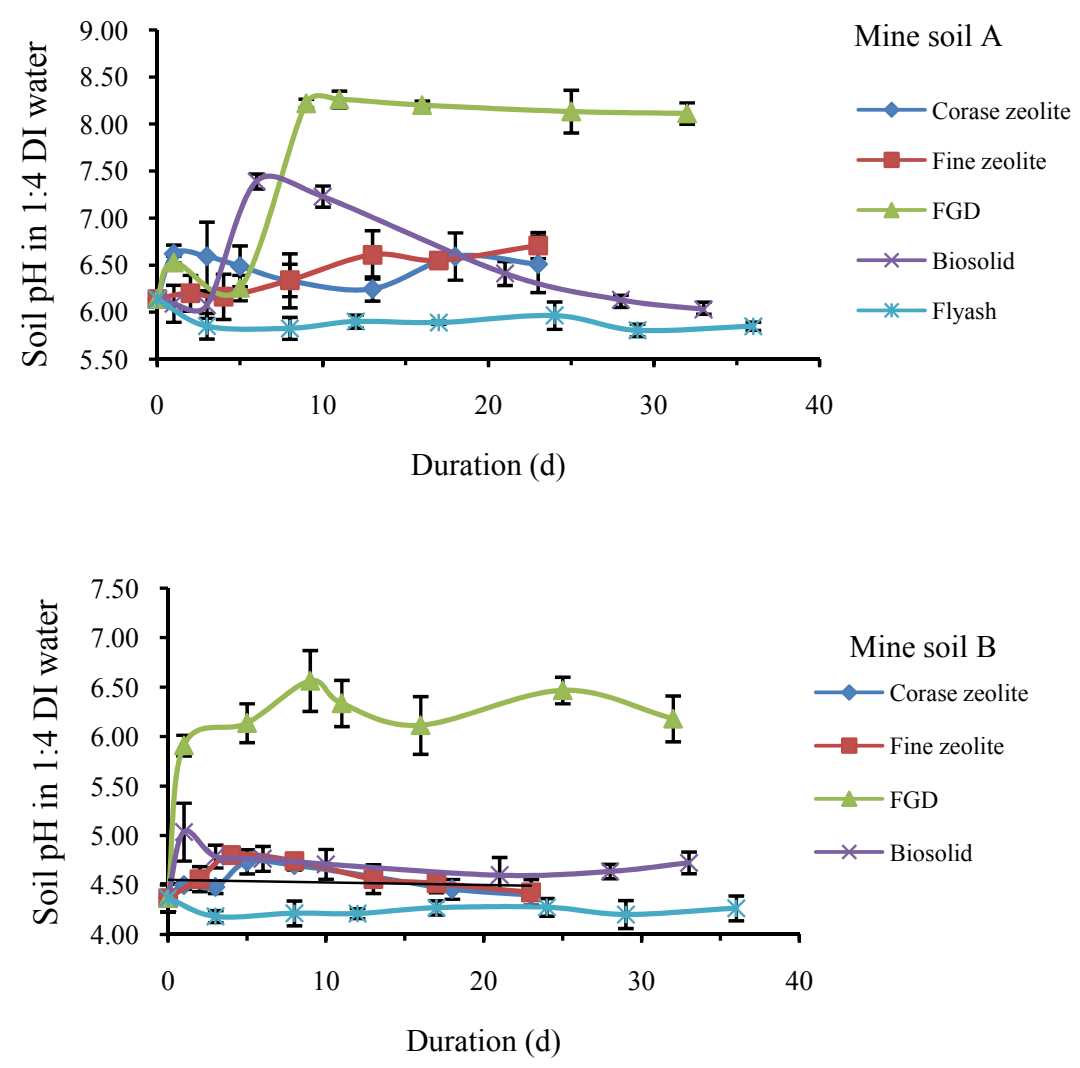

Figure 1. Effects of amendments on pH of soil A (Figure 1a, top) and soil B (Figure 1b, bottom)

Application of biosolids also increased soil $\mathrm{pH}$ to some extents: $\mathrm{pH}$ of soil A was changed from 6.14 to above 7.0 in $10 \mathrm{~d}$ and that of soil B increased from 4.37 to 5.00 in $1 \mathrm{~d}$. Biosolids usually contained some alkaline materials $\left(\mathrm{CaO}, \mathrm{Ca}(\mathrm{OH})_{2}\right.$, or $\left.\mathrm{CaCO}_{3}\right)$ which were added on purpose to increase the efficacy of the sludge digestion and to ensure the proper disposal of the wastes (USEPA, 2000). But the neutralization capacity of this 
solid was low compared with FGD: an increase of 0.2 unit was observed during the whole amendment period for soil $\mathrm{B}$ while the $\mathrm{pH}$ of soil A declined to the original level after 30 days of amendment (Figure 1). Fluctuations in soil $\mathrm{pH}$ could be explained by the fact that there was still a small portion of acid released slowly from the mine soils when exposed to the air for longer periods and some residual $\mathrm{S}$ was oxidized into $\mathrm{H}_{2} \mathrm{SO}_{4}$. Similar trends have also been observed for other materials but in a rather implicit fashion. Coarse and fine zeolites with a $\mathrm{pH}$ of around 9 increased soil $\mathrm{pH}$ by 0.4 for soil $\mathrm{A}$ from 6.14 to around 6.54 but did not significantly affect $\mathrm{pH}$ for soil B in $30 \mathrm{~d}$ although that of soil B was initially increased by 0.3 by the amendments in the first 5-8 d. This observation suggested the limited neutralization capacity of zeolite for more acidic soil such as soil B. Generally, flyash did not significantly affect the $\mathrm{pH}$ for both soils, indicating that flyash used in this test was not an ideal option for amending acidic soils or the designed application rate (10\%) was too low.

In summary, soil A, a topsoil sample, had a slightly acidic $\mathrm{pH}$ value of 6.14 , which was within the $\mathrm{pH}$ ranges of normal agricultural soils most crops grow best at a pH of 6.5 to 7.0 on most Midwestern U.S. soils (Crozier \& Hardy, 2003). For this soil, FGD significantly increase the soil pH by 3 units to alkaline levels and reaction time was about 10 days. Coarse zeolite and fine zeolite exhibited similar capacities to each other by increasing the soil $\mathrm{pH}$ by about 0.4 units. Biosolids or flyash did not significantly affect the soil $\mathrm{pH}$ of this soil in $35 \mathrm{~d}$. For sample $\mathrm{B}$, a typical acidic mine soil, the $\mathrm{pH}$ increased to around 6.5 in 10 days with the FGD amendment. However, the $\mathrm{pH}$ value fluctuated and decreased to around 6.0 in the next 25 days, suggesting that the soil contained significant amount of un-oxidized $\mathrm{S}$ and released more acids during the testing period. Therefore, frequently monitoring soil $\mathrm{pH}$ is recommended in liming acidic mine soils even when the soil $\mathrm{pH}$ is increased to a desired level. And secondary treatment (applying more liming materials in a few months) might be needed in some cases. Soil B mixed with other amendment materials did not significantly increase its $\mathrm{pH}$.

\subsection{Lettuce Seed Germination Test}

Chemical analyses of soils and soil solutions provide the chemical basis regarding soil quality and its changes. In comparison, germination test was conducted to provide direct evidence on how plants responded to mine soils and how amendments improved the mine soil quality favorable for vegetation. Germination percentage and shoot length from the germinated seeds were applied in this study to evaluate soil quality: i.e. good soils promote seed germination and shoot growth while poor soils constrain the germination and growth.

The data in Figure 2 show that an average of $77 \%$ lettuce seeds germinated in solution of blank soil A. The germination rate (Figure 2a) was statistically similar to those in DI water (87\%) and potting soil solution (88\%), indicating that this type of mine soil (topsoil) did not significantly inhibit lettuce seed germination and thus had relatively good quality comparable to DI water or the potting soil. The latter two solutions represented growing medium without contaminants or nutrients and the medium with adequate nutrients, respectively. Further, the average total length of seedlings in $5 \mathrm{~d}$ was $6.9 \mathrm{~cm}$ (Figure 2b), which was shorter than that in the potting soil solution $(10.0 \mathrm{~cm})$ but longer than that in the DI water $(4.4 \mathrm{~cm})$. The reason behind such a differential response could be that the sample A supplied some nutrients to lettuce shoots while DI water contained no nutrients. But soil A did not contain adequate nutrients compared with the potting soil. The data in Figure 2 also indicate that the lettuce germination rate and the average shoot length were not significantly enhanced by any of the amendment used. For examples, application of FGD increased the seed germination rate and shoot length to $80 \%$ and $8.1 \mathrm{~cm}$, respectively. In comparison, fine zeolite application increased the rate and length to $86.7 \%$ and 8.9 $\mathrm{cm}$, respectively. Use of coarse zeolite, on the other hand, increased the germination rate to $90 \%$ but decreased the shoot length to $6.4 \mathrm{~cm}$. However, these responses to soil amendments were not statistically significant (Figure 2). In addition, biosolids significantly improved the lettuce seed germination rate to $100 \%$ but shoot length $(6.5 \mathrm{~cm})$ was slightly reduced (not statistically different though) compared with that in the unamended soil $(6.9 \mathrm{~cm})$. In comparison, the flyash reduced both germination rate $(70 \%$, not statistically significant difference) and shoot length $(3.5 \mathrm{~cm}$, statistically significant difference). In summary, the amendments used in this study did not significantly improve the quality of soil A nor the lettuce seed germination or seedling elongation. Such a response may be attributed to the following reason: soil A was a type of mine soil derived from the original topsoil without being seriously affected by the mining activities and thus had relatively good soil quality. These types of mine soils were highly weathered, contained no or little acid-producing minerals, and often have normal $\mathrm{pH}$ values. Ussiri et al. (2006) reported the $\mathrm{pH}$ values of top soils from Ohio reclaimed mining sites (13-28 years old, respectively) ranged from 6.9 8.1 under different vegetation. Besides, the good chemical quality of the original top soils was also reflected in the relative good performance of the lettuce seed in soil A solution. Thus, the amendment materials used for improving soil quality by correcting soil acidity (by FGD) or/and reducing elemental toxicity (by zeolite) did not significantly improve plant performance in the soil because it had relatively neutral value and did not contain significant level of toxins (Tables 1 and 2). Instead, deficiency of 
plant nutrients (esp. N and P) or poor soil physical properties (such as soil compaction or low water holding capacity) might be the major constraints to sustainable vegetation establishments in reclaimed mining sites.

In contrast, soil B is a typical mine soil (coarse coal refuse) with higher acidity and lower soil $\mathrm{pH}$. Therefore, application of alkaline amendments improved the quality of soil B to varying degrees in term of lettuce germination (Figure 3). For example, lettuce seed germination rate in solution of antecedent soil B was $60 \%$ on average, lower than those in DI water (86.7\%), in the potting soil solution $(88.0 \%)$, or in soil A solution (77\%). The average length of surviving lettuce shoots in soil B was $3.7 \mathrm{~cm}$, again lower than that in DI water $(4.4 \mathrm{~cm})$, or half the length of that in
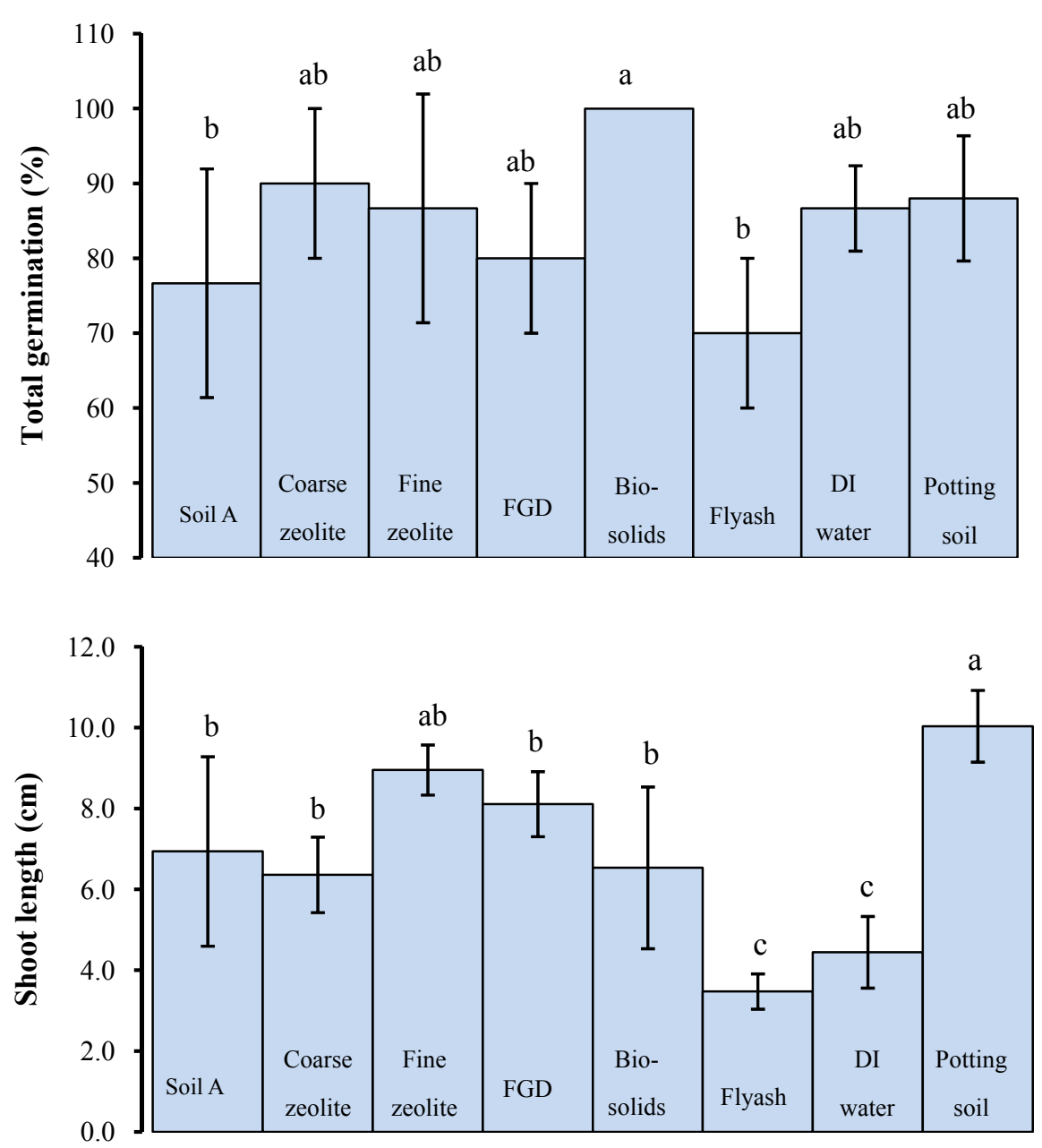

Figure 2. Effects of amendments on lettuce seed germination in 1:4 solution of soil A: germination percentage (Figure 2a, top) and shoot length (Figure 2b, bottom). Values with different lowercase letters are significantly different by Tukey test $(\mathrm{p}<0.05)$ 

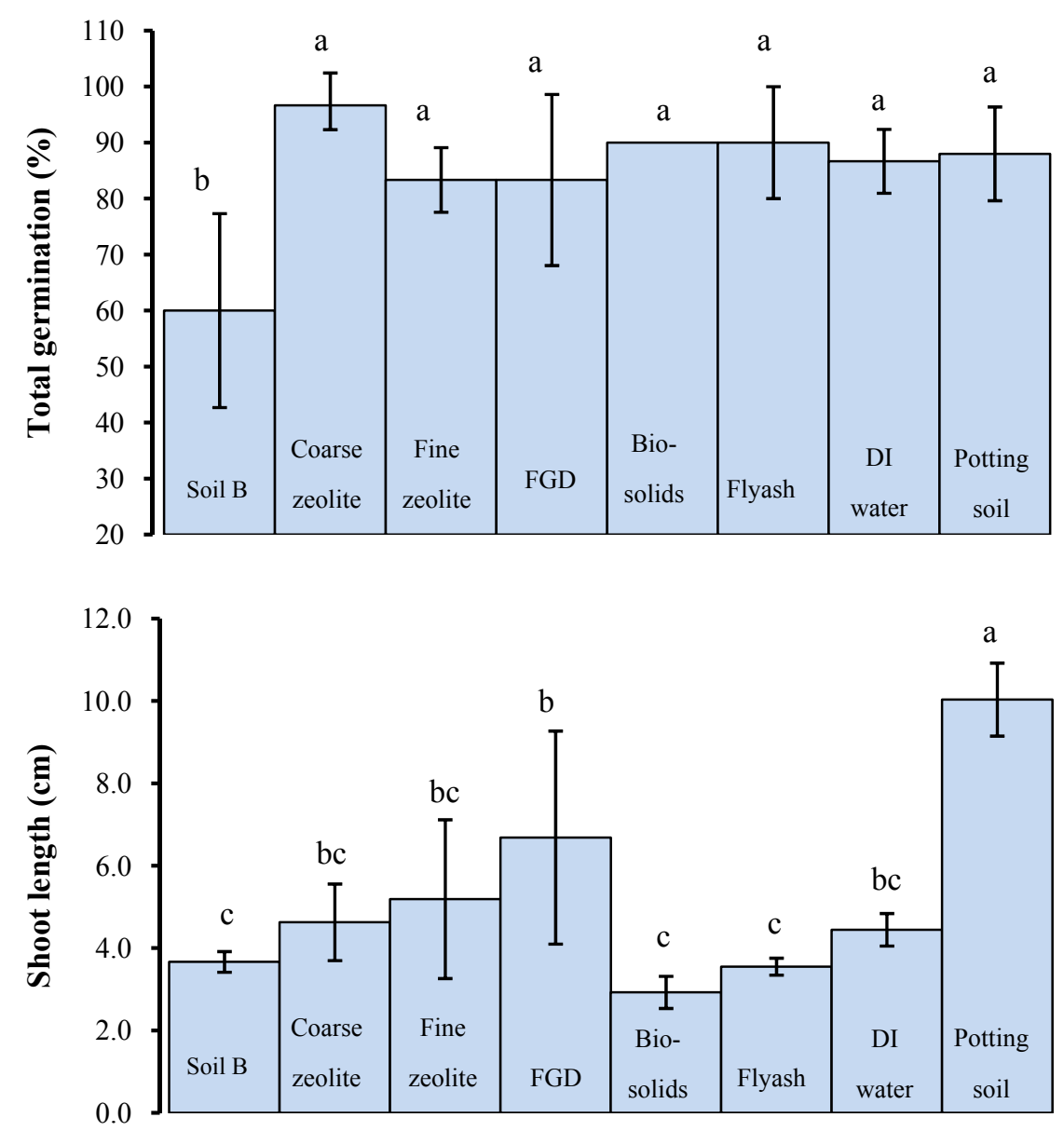

Figure 3. Effects of amendments on lettuce seed germination in 1:4 solution of soil B: germination percentage (Figure 3a, top) and shoot length (Figure 3b, bottom). Values with different lowercase letters are significantly different by Tukey test $(\mathrm{p}<0.05)$

soil A, or only one third of the size in potting soil solution. Both germination rate and shoot length indicated the relatively lower quality of this soil compared with that of soil A. In addition, application of amendments significantly improved the quality of the former. For example, all amendments increased the lettuces seeds surviving rate from antecedent level of $60 \%$ to $83 \%$ - 97\% (Figure 3a). Moreover, use of FGD significantly increased the shoot length from $3.7 \mathrm{~cm}$ to $6.7 \mathrm{~cm}$. And both fine and coarse zeolites enhanced the lettuce growth (4.6 and $5.2 \mathrm{~cm}$, respectively) as well but not statistically significantly. Addition of biosolids and flyash into soil $\mathrm{B}$, instead, inhibited the shoot elongation $(2.9 \mathrm{~cm}$ and $3.6 \mathrm{~cm}$, respectively) (Figure $3 \mathrm{~b}$ ). In summary, data in Figure 3 suggest that soil acidity was the major constraint of soil B for lettuce seed germination and shoot growth. In other words, soil B had worse quality than that of soil A because the former was more acidic. Thus, any amendment which could neutralize soil acidity (Figure1) would enhance the lettuce seed germination and shoot elongation and thus improve the soil quality. The prominent enhancement of lettuce seed germination and growth in soil B by FGD (Figure 3) should be attributed to its highest capacity of acidity neutralization (Figure 1).

Low soil pH often increases the solubility of toxic metals such as $\mathrm{Al}$ (III) and Mn (II) in the soil solution. These elements not only impair the physiological functions of plants but also interfere the uptake of essential elements (e.g., $\mathrm{Ca}, \mathrm{Mg}$, and $\mathrm{P}$ ). Therefore, plants grown in acid soils can experience a variety of symptoms including $\mathrm{Al}, \mathrm{H}$, and/or Mn toxicity, as well as potential nutrient deficiencies of $\mathrm{Ca}$ and $\mathrm{Mg}$. Toxicity of $\mathrm{Al}$ is the most widespread problem in acid soils where the $\mathrm{pH}$ is $<5.5$. When soil $\mathrm{pH}$ is $<4, \mathrm{H}^{+}$ions themselves damage root cell membranes. Low $\mathrm{pH}$ also interrupts the beneficial microbial activities such as biological nitrogen fixation. Therefore, $\mathrm{pH}$ management by amendments is needed if the mine soil $\mathrm{pH}$ is too low for successful vegetation establishment. Liming is a traditional and effective soil amendment to increase the $\mathrm{pH}$ values of an acidic mine 
soil. Other alkaline indusial wastes/by-products such as FGD and flyash from coal power plants and red-mud from aluminum refineries have also been used. However, the mine soil is not always acidic if a soil does not contain pyrites, it contains enough carbonates, or in cases where pyrites are buried deep underneath the soil and thus are not exposed to the air. In those cases, using liming materials may not greatly improve the vegetation establishments. In general, soil tillage and fertilizer application are usually beneficial to reclamation of these neutral or alkaline mine soils for biomass production.

\subsection{Effects of Amendments on Soil Physical Properties}

Besides soil acidity, mine soils also have poor soil physical properties or soil structures including high sand fraction, high bulk density due to soil compaction, and low aggregation and stability, which usually result in low holding capacity of plant-available-water (PAW), high mechanical resistance to root penetration, and high vulnerability to soil erosion, which together adversely affect plant establishment and development. Effects of the amendments on soil aggregate stability and PAW were assessed in this study in order to know whether these materials could improve physical properties of mine soils.

\subsubsection{Water Stability of Soil Aggregates}

Structural stability is one of the most important physical characteristics of cultivated soils. It measures the extent to which soil aggregates are likely to remain intact and separate from one another by rainfall (water erosion) or by mechanical disturbance (wind erosion) (Kemper \& Rosenau, 1986). The data in Figure 4 show how the mean weight diameter (MWD) of two mine soils changed with the amendments. Application of biosolids significantly increased the MWD of soil A by 1.6 times from 0.97 to $1.61 \mathrm{~mm}$ and that of soil B by 1.3 times from 0.90 to $1.16 \mathrm{~mm}$, indicating the important role of the biosolids in enhancing soil aggregate stability and in reducing vulnerability to soil erosion by water. Use of other amendments did not significantly benefit the soil structural stability (Figure 4). For examples, flyash increased the MWD of soil A from 0.97 to $1.05 \mathrm{~mm}$ while reduced that of soil B from 0.90 to $0.86 \mathrm{~mm}$.

Soil aggregate stability is generally strongly correlated with soil organic matter content (Tisdall \& Oades, 1982; Chaney \& Swift, 1984; Haynes \& Swift, 1990). Further, increase in aggregation through biosolids amendment has been observed by several researchers (Garcia-Orenes et al., 2005; Ojeda et al., 2008; Wallace et al., 2009). For example, after 2 years of digested-biosolids application to a soil surface at a rate of $15 \mathrm{Mg} \mathrm{ha}^{-1}$, Ojeda et al. (2008) found that MWD of this loamy soil increased by 1.25 times from 2 to $2.5 \mathrm{~mm}$. The stable aggregate percentage of two soils studied by Garcia-Orences et al. (2005) increased by 1.8-3.7 folds in comparison to the control. Wallace et al. (2009) reported that application of $60 \mathrm{Mg} \mathrm{ha}^{-1}$ of dry biosolids resulted in about $50 \%$ more larger aggregates $(2-6 \mathrm{~mm})$ relative to the control and increased the MWD from 1.2 to $1.5 \mathrm{~mm}$. It is widely believed that biosolids application provides the soils with abundant OM which works as an aggregate-binding agent and increases the soil aggregate size and stability. However, options differed regarding specific groups of organic compounds as the most effective binding agents. Some researchers argued that the major binding chemicals in the biosolids are the labile fraction of carbohydrates (more specifically, polysaccharides) (Garcia-Orenes et al., 2005; Ojeda et al., 2008). Yet others opinedthat humic fraction of the SOM were more important to soil aggregation than the carbohydrates (Piccolo \& Mbagwu, 1990; Spaccini et al., 2002). We believed that biosolids are a relatively stable mixture of organic matter which has been subject to intensive bio-degradation through anaerobic digestion in the wastewater treatment plant. Therefore, the labile fraction (e.g., polysaccharides) should be either very low or none in the solids. The stable OM faction-the humic faction might play more important role in biosolids for enhancing soil aggregation.In comparison, the inorganic counterparts (such as zeolites, FGD, and flyash) did not significantly improve soil aggregation because these materials did not contain the cementing organic matter. Soil MWD decreased with fly ash amendments was also observed by Salé et al. (1996). 

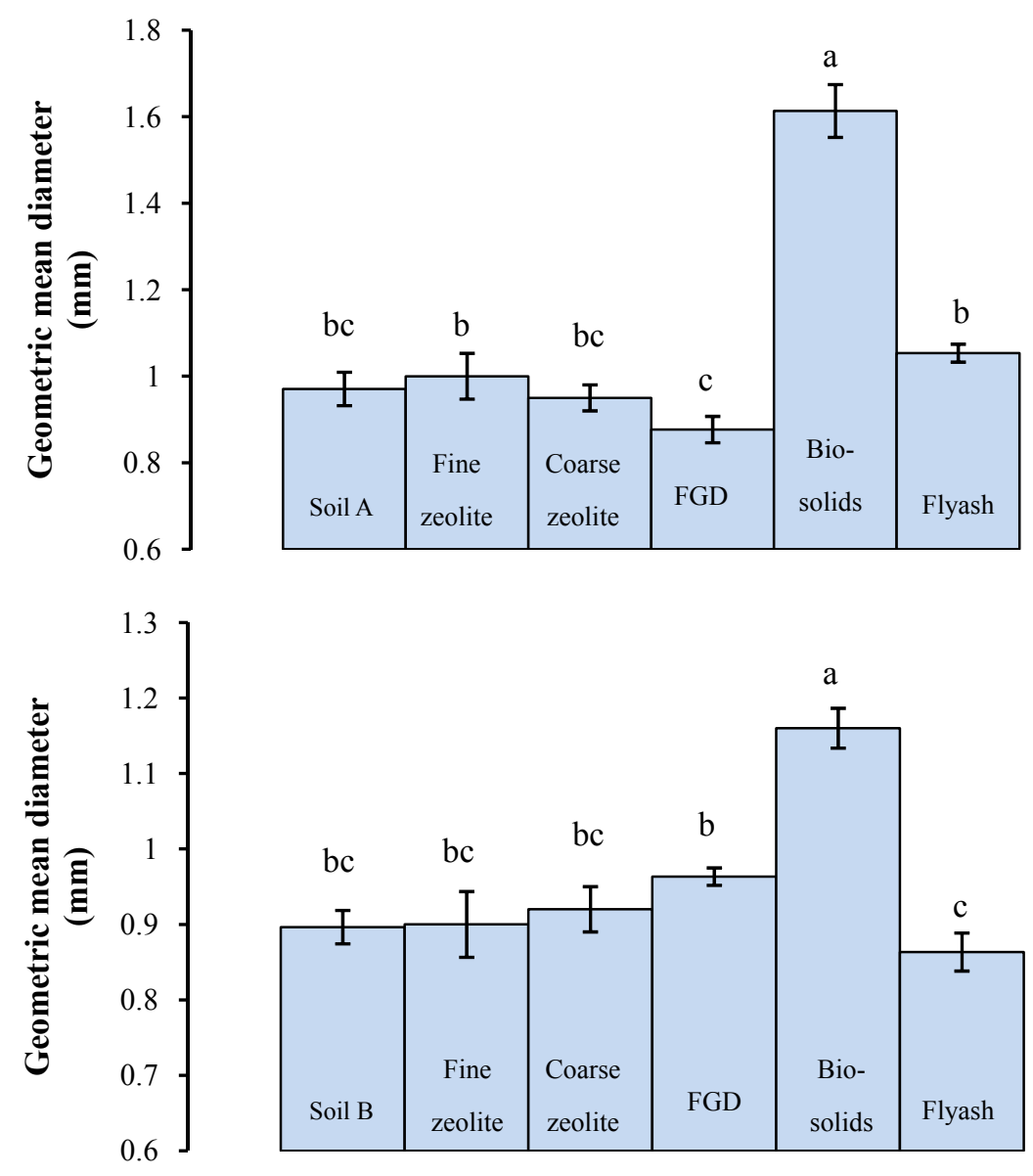

Figure 4. Effects of amendments on mean weigh diameter of water-stable aggregates in soil A (Figure 4a, top) and soil B (Figure 4b, bottom). Values with different lowercase letters are significantly different by

Tukey test $(\mathrm{p}<0.05)$

\subsubsection{Water Holding Capacity}

High soil WHC is important to re-vegetation on a closed mining site where the PAW depends on only the precipitations. However, mine soils often have poor WHC because of their coarse texture. Two important parameters regarding soil WHC were addressed in the study: saturated-water holding capacity (SWHC) and plant-available water holding capacity (PAWHC). The former refers to WHC of a soil when it is fully saturated, as right after a rainfall (measured at $0 \mathrm{MPa}$ matric potential, i.e., in the atmospheric pressure). The latter means the soil's capacity of holding water available for plant use in the field and is usually estimated by the difference of the soil field capacity (WHC measured at $-0.03 \mathrm{MPa}$ ) and the permanent wilting point (WHC at $-1.5 \mathrm{MPa}$ ) (Cassel \& Nielsen, 1986). The data presented show that some amendments effectively enhanced the mine soil SWHC (Figure 5). For example, the un-amended soil A had a SWHC of $47.2 \%$ and the application of fine zeolite increased it to 53.1\%. Similarly, FGD, biosolids, and the coarse zeolite increased SWHC to 52.7, 52.0, and 50.6\%, respectively. But, flyash amendment did not significantly affect the SWHC of this soil $(47.9 \%$, not a statistically significant change). Interestingly, soil B had unusually high SWHC of $77.3 \%$, and all the amendments showed either no effects or reduced the SWHC of this soil. The fine zeolite amendment, for instance, decreased the SWHC to $61.9 \%$. Biosolids application reduced the SWHC to $66.5 \%$ on average but the effect was not statistically significant. The WHC of a soil often depends on the soil texture (Saxton et al., 1986; Kern, 1995). The data presented here show that texture of soil A was sandy loam $(65.8 \%$ sand, $27.6 \%$ silt, and $6.7 \%$ clay) while that of soil B was loam ( $47.5 \%$ sand, $40 \%$ silt, and $12.5 \%$ clay). Soils with higher percentage of fine fractions (clay + silt) usually retain more moisture than those with higher percentage of coarser fraction (sand). Fine particles possess higher surface areas and smaller inter-particle pore space, both of which increase water retention capacity of soil even under higher matric potential (e.g. 1.5 MPa). The higher sand fraction in 
soil A resulted in lower water retention capacity (47.2\%) and soil amendments (esp. fine zeolites, particle size < $40 \mu \mathrm{m})$ may have increased the silt fraction of this soil and thus increased the SWHC of this soil. In comparison, soil B contained higher portion of fine fractions and thus had higher SWHC than soil A. And, no amendment significantly changed the texture of soil B and thus did not significantly affect its SWHC. Different degree of weathering might have caused the high content of small particles in soil B compared with soil A.

For similar reasons, soil B had a higher PAWHC (18.1\%) than that of soil A (12.4\%) (Figure 6), indicating soil $\mathrm{B}$ could retain and provide more water to plants than soil A. In addition, application of amendments did not significantly enhance the PAWHC of either soil (Figure 6). By definition, PAWHC of a soil is the diffidence between moisture contents at field capacity and permanent wilting point. Thus, slight changes of WHC (both field capacity and wilting point) by the amendments might not cause any significant change of the PAWHC. However, biosolids application resulted in a significant decrease of the PAWHC of soil B from $18.2 \%$ to $15.7 \%$. The data in this study show that biosolids amendment increased the field capacity of soil B from 33.1 to $35.1 \%$ (a $2.0 \%$ increase) while the permanent wilting point was also increased by the amendment from 15.0 to $19.5 \%$ (a $4.5 \%$ increase). Therefore the net change of the PAWHC by biosolids amendment was $-2.5 \%$. Biosoilds also resulted in a decrease of PAWHC of soil A by $0.7 \%$, but the decrease was not statistically significant (Figure 7a).

Khaleel et al. (1981) summarized the effects of organic matter amendments on WHC as being in two folds: i) WHC (weight basis) including saturated water content, field capacity and permanent witling point all increase with OM additions, and the enhanced WHC at lower matric potential (saturated water content or field capacity) was due to an increase of the small pore number in soils by the OM amendments while an increase of the soil surface areas by OM resulted in the increased WHC at higher matric potential (permanent witling point). ii) But the magnitude of increases varied with soil texture. For fine-textured soils, an increase in WHC at field capacity was greater than at the permanent wilting point, resulting in a net increase of the PAWHC by the amendment. For coarse-textured soils, such as the mine soils in the present study, high percentage of sand present in the soils produced a larger increase in WHC at permanent wilting point than at the field capacity, thus decreasing the PAWHC by the OM amendment as was observed in this study. Therefore, increases in organic $\mathrm{C}$ concentration increased in the soil moisture content at both the field capacity and wilting point, leading to no net gains in soil PAWHC.

\section{Conclusions}

Mine soils usually have poor chemical and/or physical quality as growing media in comparison with the fertile agricultural soils. Thus, soil amendments are often needed to improve mine soil quality for re-vegetation. However, different mine soils may respond differently to a same amendment material. In the present study, two coal mine soils from different sources and with different properties were evaluated for changes in soil property in response to soil amendments.

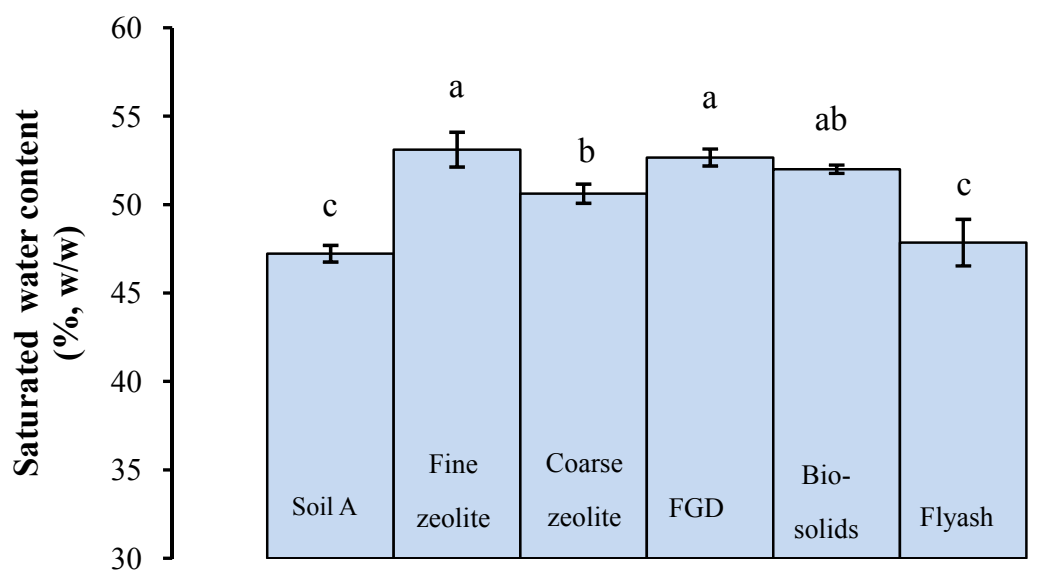




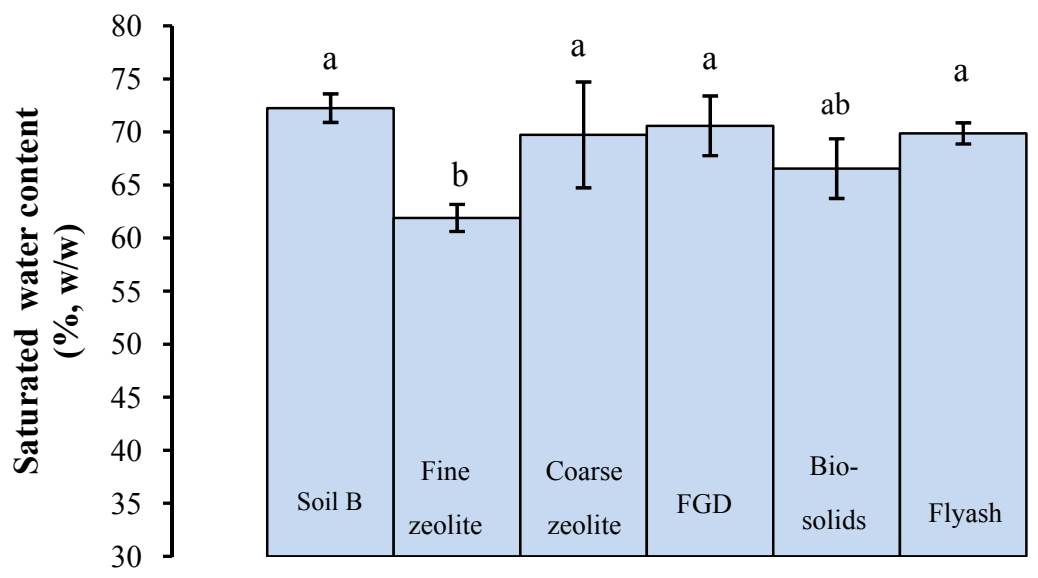

Figure 5. Effects of amendments on saturated- water holding capacity of soil A (page 14, bottom) and soil B (top). Values with different lowercase letters are significantly different by Tukey test $(\mathrm{p}<0.05)$
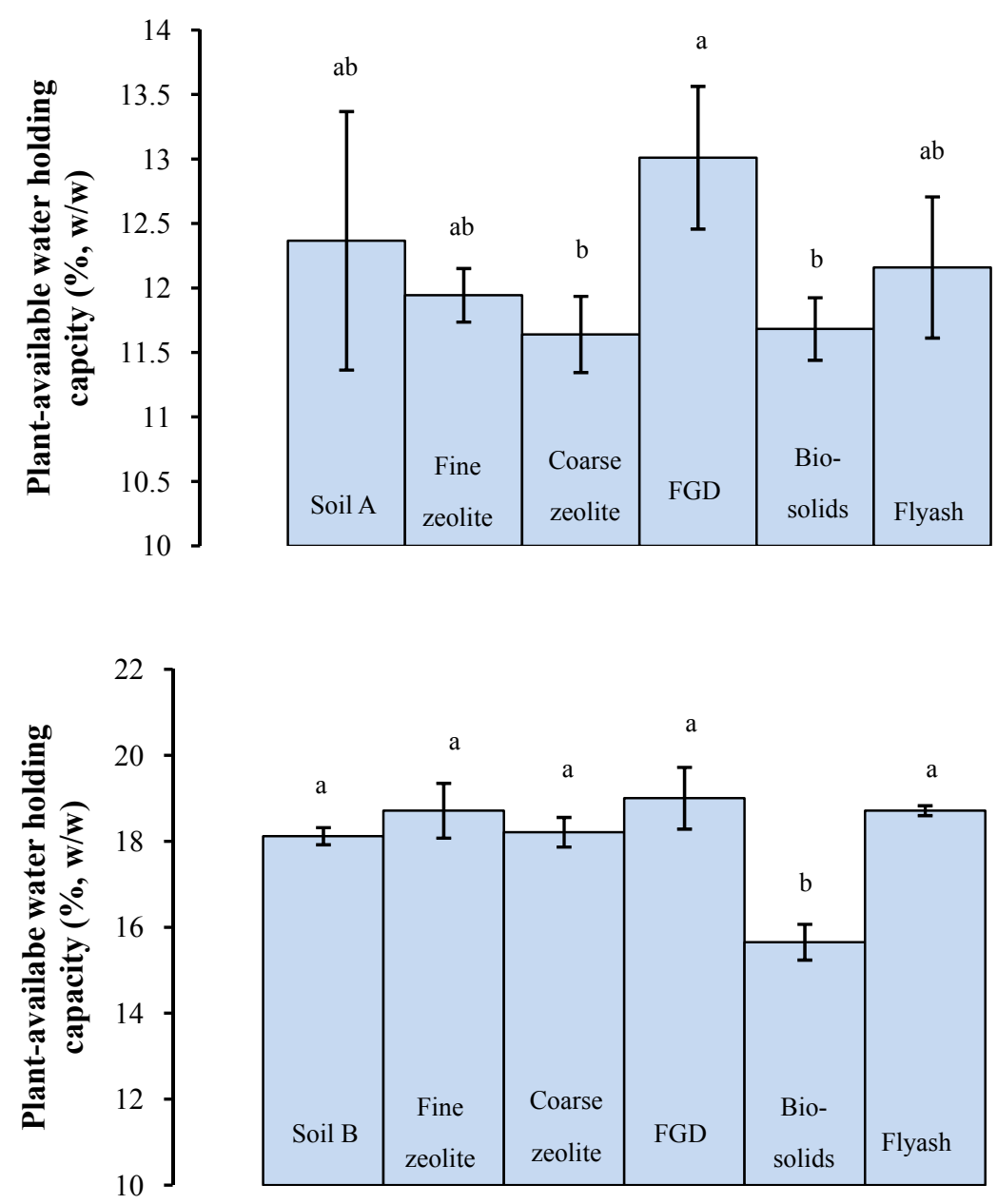

Figure. 6 Effects of amendments on plant-available water holding capacity of mine soil A (top) and mine soil B (bottom). Values with different lowercase letters are significantly different by Tukey test $(p<0.05)$

One soil sample was taken from the top soil at a reclaimed site while the other taken from nearby piles of coarse coal refuse, which was excavated with coal but abandoned due to low coal content. With proper reclamation and management, both soils could be used for biomass production. Chemical analysis showed that neither soil 
contained significant amounts of toxic elements except for B or Sr, and the levels of other heavy metals were similar to those present in agricultural soils in the region. Lettuce seed germination test indicated that soil acidity might be the major chemical factor inhibiting plant establishment in soil B and the amendments such as FGD increased soil $\mathrm{pH}$ close to the neutral level and enhanced lettuce seedling growth in this soil. In contrast, no amendment significantly further improved the lettuce seedling growth in soil A because this soil had neutral $\mathrm{pH}$ value and thus relatively better original quality for lettuce seed growth. These data suggest that liming materials such as FGD or limestone would not significantly improve the soil quality if the soils are not acidic. Instead, the soil physical properties (WHC, soil depth, or soil compaction) or nutrient availability ( $\mathrm{N}$ or $\mathrm{P}$ ) are the limiting factors to successful vegetation establishment on these mine soils. Therefore, there is no universally suitable amendment materials for all types of mine soils, and soil amendments should be selected on the basis of antecedent soil properties.

With regard to soil physical properties, application of biosolids enhanced aggregate stability of both soils by increasing GMD from antecedent to $0.90-0.97 \mathrm{~mm}$ to $1.2-1.6 \mathrm{~mm}$. Thus, biosolids are a good cementing agent for improving soil aggregation. Soil B possessed higher water holding capacity than soil A due to relative finer texture. Application of the amendments slightly increased the SWHC of soil A to varying degrees $(<6 \%)$, but did not affect that of soil B. Moreover, the amendments did not significantly improve PAWHC of either soil. Instead, biosolids amendment reduced PAWHC of both soils.

In conclusion, application of FGD, a liming material, significantly increased the acidic soil $\mathrm{pH}$ from 4.4 to 6.0 and enhanced lettuce seeds germination and shoot growth but had no significantly beneficial effects on lettuce grown in the neutral soil although the soil $\mathrm{pH}$ was increased from 6.1 to 8.0. Biosolids prominently increased soil aggregate stability but slightly reduced soil PAWHC. Zeolites and flyash did not significantly impact the mine soil quality.

\section{References}

Angel, P. N., Barton, C. D., Warner, R. C., Agouridis C., Taylor., T., \& Hall, S. L. (2008). Forest establishment and water quality characteristics as influenced by spoil type on a loose-graded surface mine in eastern Kentucky. In R. I. Barnhisel (Ed.), Proceedings of the National Meeting of the American Society of Mining and Reclamation: new opportunities to apply our science, Richmond, VA. (June 14-19, 2008, pp. 28-65). Lexington, KY: American Society for Surface Mining and Reclamation,

ATSDR-Agency for Toxic Elements and Disease Registry. (2002). Public health statement-strontium (CAS\# 7440-24-6). Retrieved from http://www.atsdr.cdc.gov/phs/phs.asp?id=654\&tid=120

Bendfeldt, E. S., Burger, J. A., \& Daniels, W. L. (2001). Quality of amended mine soils after sixteen years. Soil Science Society of America Journal, 65, 1736-1744. http://dx.doi.org/10.2136/sssaj2001.1736

Bhumbla, D. K., Singh, R. N., \& Keefer, R. F. (2000). Coal combustion by-product utilization for land reclamation. In R. I. Barnhisel, R. G. Darmody, \& W. L. Daniels (Eds.), Reclamation of drastically disturbed lands (pp. 489-512). Madison, WI: American Society of Agronomy; Crop Science Society of America; Soil Science Society of America.

Bohn, H. L., McNeal, B. L., \& O’Connor, G. A. (1979). Soil chemistry. New York, NY: JohnWiley \& Sons.

Bowers, N., Pratt, J. R., Beeson, D., \& Lewis, M. (1997). Comparative evaluation of soil toxicity using lettuce seeds and soil ciliates. Environmental Toxicology \& Chemistry, 16, 207-213. http://dx.doi.org/10.1002/etc.5620160216

Bremner, J. M. (1996). Nitrogen-total. In D. L. Sparks (Ed.), Methods of soil analysis, part III, chemical methods (pp. 1085-1121). Madison, WI: American Society of Agronomy, Crop Science Society of America, Soil Science Society of America.

Cassel, D. K., \& Nielsen, D. R. (1986). Field capacity and available water capacity. In A. Klute (Ed.). Methods of soil analysis, part I, physical and mineralogical methods. (2nd ed., pp. 635-662). Madison, WI: American Society of Agronomy, Soil Science Society of America.

Clark, R. B., Ritchey, K. D., \& Baligar, V. C. (2001). Benefits and constraints for use of FGD products on agricultural land. Fuel, 80, 821-827. http://dx.doi.org/10.1016/S0016-2361(00)00162-9

Chaney, K., \& Swift, R. S. (1984). The influence of organic matter on aggregate stability in British soils. Journal of Soil Science, 35, 223-230. http://dx.doi.org/10.1111/j.1365-2389.1984.tb00278.x

Cox, C. A., \& Colvin, G. H. (1996). Evaluation of background metal concentrations in Ohio soils. Retrieved from www.coxcolvin.com/documents/OhioBackgroundMetals.pdf 
Coyne, M. S., Zhai, Q., Mackown, C. T., \& Barnhisel, R. I. (1998). Gross nitrogen transformation rates in soil at a surface coal mine site reclaimed for prime farmland use. Soil Biology \& Biochemistry, 30, 1099-106. http://dx.doi.org/10.1016/S0038-0717(97)00202-2

Crews, J. T., \& Dick, W. A. (1998). Liming acid forest soils with flue gas desulfurization by-product: Growth of northern read oak and leachate water quality. Environmental Pollution, 103, 55-61. http://dx.doi.org/10.1016/S0269-7491(98)00137-7

Crozier, C. R., \& Hardy, D. H. (2003). Soil facts: Soil acidity and liming-basic information for farmers and gardeners. Publ. AGW-439-51, North Carolina Cooperative Extension. Retrieved from http://wwwsoil.ncsu.edu/publications/Soilfacts/AG-439-51.Accessed on 3 February 2013

Daniels, W. L., \& Haering, K. C. (1994). Use of sewage sludge for land reclamation in the central Appalachians. In C. E. Clapp, W. E. Larson, \& R. H. Dowdy (Eds.), Sewage sludge: Land utilization and the environment (pp. 105-121). Madison, WI:American Society of Agronomy, Crop Science Society of America, Soil Science Society of America.

Daniels, W. L., \& Stewart, B. R. (2000). Reclamation of Appalachian coal refuse disposal areas. In R. I. Barnhisel, R. G. Darmody, \& W. L. Daniels (Eds.), Reclamation of drastically disturbed lands (pp. 433-459). Madison, WI: American Society of Agronomy, Crop Science Society of America, Soil Science Society of America.

Daniels, W. L., Stewart, B., Haering, K. C., \& Zipper, C. (2002). The potential for beneficial reuse of coal fly ash in southwest Virginia mining environments. Virginia Cooperative Extension (VCE) publication 460-134. Retrieved from http://ww.pubs.ext.vt.edu/460-134

Daniels, W. L., Stewart, B., \& Zipper, C. (2010). Reclamation of coal refuse areas (pp. 460-131). Virginia $\begin{array}{lllll}\text { Cooperative } & \text { Extension } & \text { (VCE) } & \text { publication. } & \text { Retrieved }\end{array}$ http://pubs.ext.vt.edu/460/460-131/460-131_pdf.pdf

DeSutter, T. M., Cihacek, L. J., \& Raham, S. (2014). Application of flue gas desulfurization gypsum and its impact on wheat grain and soil chemistry. Journal of Environmental Quality, 43, 303-311. http://dx.doi.org/10.2134/jeq2012.0084

Dick, W. A., Stehouwer, R. C., Bigham, J. M., Wolfe, W. E., Hao, Y. L., Adriano, D., ... Haefner, R. J. (2000). Beneficial uses of flue gas desulfurization by-products: Examples and case studies of land application. In J. F. Power \& W. A. Dick (Eds.), Land application of agricultural, industrial, and municipal by-products (pp. 505-536). Madison, WI: Soil Science Society of America.

Forsberg, L. S., \& Ledin, S. (2006). Effects of sewage sludge on pH and plant availability of metals in oxidising sulphide mine tailings. Science of the Total Environment, 358, 21-35. http://dx.doi.org/10.1016/j.scitotenv.2005.05.038

Garci'a-Orenes, F., Guerrero, C., Mataix-Solera, J., Navarro-Pedreño, J., Gómez, I., \& Mataix-Beneyto, J. (2005). Factors controlling the aggregate stability and bulk density in two different degraded soils amended with biosolids. Soil Tillage Research, 82, 65-76. http://dx.doi.org/10.1016/j.still.2004.06.004

Gee, G. W., \& Bauder, J. W. (1986). Particle-size analysis. In A. Klute (Ed.), Methods of soil analysis, part I, physical and mineralogical methods (2nd ed., pp. 383-411). Madison, WI: American Society of Agronomy, Soil Science Society of America.

Gelfand, I., Sahajpal, R., Zhang, X., Izaurralde, R. C, Gross, K. L., \& Robertson, G. P. (2013). Sustainable bioenergy production from marginal lands in the US Midwest. Nature, 493, 514-517. http://dx.doi.org/10.1038/nature11811

Haering, K. C., Daniels, W. L., \& Feagley, S. E. (2000). Reclaiming mined lands with biosolids, manures and paper mill sludges. In R. I. Barnhisel, R. G. Darmody \& W. L. Daniels (Eds.), Reclamation of drastically disturbed lands (pp. 615-644). Madison, WI: American Society of Agronomy; Crop Science Society of America; Soil Science Society of America.

Haynes, R. J., \& Swift, R. S. (1990). Stability of soil aggregates in relation to organic constituents and soil water content. Journal of Soil Science, 41, 73-83. http://dx.doi.org/10.1111/j.1365-2389.1990.tb00046.x

Jacinthe, P. A., \& Lal, R. (2007). Carbon storage and minesoil properties in relation to topsoil application techniques. Soil Science Society of America Journal, 71, 1788-1795. http://dx.doi.org/10.2136/sssaj2006.0335 
Kabata-Pendias, A., \& Pendias, H. (1984). Trace elements in soils and plants. Boca Raton, FL: CRC Press.

Kepmer, W. D., \& Rosenau, R. C. (1986). Aggregate stability and size distribution. In A. Klute (Ed.), Methods of soil analysis, part I, physical and mineralogical methods (2nd ed. pp. 425-442). Madison, WI: American Society of Agronomy, Soil Science Society of America.

Kern, J. S. (1995). Evaluation of soil water retention models based on basic soil physical properties. Soil Science Society of America Journal, 59, 1134-1141. http://dx.doi.org/10.2136/sssaj1995.03615995005900040027x

Khaleel, R., Reddy, K. R., \& Overcash, M. R. (1981). Changes in soil physical properties due to organic waste applications: A review. Journal of Environmental Quality, 10, 133-141. http://dx.doi.org/10.2134/jeq1981.00472425001000020002x

Kost, D. A., Bigham, J. M., Stehouwer, R. C., Beeghly, J. H., Fowler, R., Traina, S. J., ... Dick, W. A. (2005). Chemical and physical properties of dry flue gas desulfurization products. Journal of Environmental Quality, 34, 676-686. http://dx.doi.org/10.2134/jeq2005.0676

Lal, R., \& Bruce, J. P. (1999). The potential of world cropland to sequester carbon and mitigate the greenhouse effect. Environmental Science \& Policy, 2, 177-185. http://dx.doi.org/10.1016/S1462-9011(99)00012-X

Larney, F. J., Akinremi, O. O., Lemke, R. L., Klaassen, V. E., \& Janzen, H. H. (2005). Soil responses to topsoil replacement depth and organic amendments in wellsite reclamation. Canadian Journal of Soil Science, 85, 307-317. http://dx.doi.org/10.4141/S04-035

Li, R. S., \& Daniels, W. L. (1997). Reclamation of coal refuse with papermill sludge amendment. In Conference Proceedings of the National Meeting of the American Society for Surface Mining and Reclamation, Austin, TX. 10-15 May 1997 (pp. 277-289). Lexington, KY: American Society for Surface Mining and Reclamation.

Logan, T. J., \& Miller, R. H. (1983). Background levels of heavy metals in Ohio farm soils. The Ohio State University, Ohio Agricultural Research and Development Center, Research Circular 275. Retrieved from http://ohioline.osu.edu/rc275/

Nabuurs, G. J., Dolman, A. J., Verkaik, E., Kuikmana, P. J., van Diepena, C. A.,Whitmore, A. P., ... Mohrene, G. M. J. (2000). Article 3.3 and 3.4 of the Kyoto protocol: Consequences for industrialized countries' commitment, the monitoring needs and possible side effects. Environmental Science \& Policy, 3, 123-134. http://dx.doi.org/10.1016/S1462-9011(00)00006-X

National Mining Association. (2012). 2011 Coal producer survey. Retrieved from http://www.nma.org $/ \mathrm{pdf} / \mathrm{members} /$ coal_producer_survey2011

Nelson, D. W., \& Sommers, L. E. (1996). Total carbon, organic carbon, and organic matter. In D. L. Sparks (Ed.), Methods of soil analysis, part III, chemical methods (pp. 961-1010). Madison, WI: American Society of Agronomy, Crop Science Society of America, Soil Science Society of America.

Ojeda, G., Alcaniz, J. M., \& Bissonnais, Y. L. (2008). Differences in aggregate stability due to various sewage sludge treatments on a Mediterranean calcareous soil. Agriculture, Ecosystems \& Environment, 125, 48-56. http://dx.doi.org/10.1016/j.agee.2007.11.005

Piccolo, A., \& Mbagwu, J. S. C. (1990). Effects of different organic waste amendments on soil microaggregates stability and molecular sizes of humic substances. Plant \& Soil, 123, 27-37.

Roberts, J. A., Daniels, W. L., Bell, J. C., \& Zipper, C. E. (1988). Early stages of mine soil genesis as affected by top soiling and organic amendments. Soil Science Society of America Journal, 52, 730-738. http://dx.doi.org/10.2136/sssaj1988.03615995005200030025x

Salé, L. Y., Chanasyk, D. S., \& Naeth, M. A. (1996). Temporal influence of fly ash on soil bulk density and aggregate size distribution. Proceedings of the 20th Annual British Columbia Mine Reclamation Symposium (pp. 184-195). Kamloops, BC, Canada.

Saxton, K. E., Rawls, W. J., Romberger, J. S., \& Papendick, R. I. (1986). Estimating generalized soil-water characteristics from texture. Soil Science Society of America Journal, 50, 1031-1036. http://dx.doi.org/10.2136/sssaj1986.03615995005000040039x

Scencindiver, J. C., \& Ammona, J. T. (2000). Minesoil genesis and classification. In R. I. Barnhisel, R. G. Darmody, \& W. L. Daniels (Eds.), Reclamation of drastically disturbed lands (pp. 595-613). Madison, WI: American Society of Agronomy; Crop Science Society of America; Soil Science Society of America. 
Shipitalo, M. J., \& Bonta, J. V. (2008). Impact of using paper mill sludge for surface-mine reclamation on runoff water quality and plant growth. Journal of Environmental Quality, 37, 2351-2359. http://dx.doi.org/10.2134/jeq2007.0648

Shrestha, R. K., Lal, R., \& Jacinthe, P. A. (2009). Enhancing carbon and nitrogen sequestration in reclaimed soils through organic amendments and chiseling. Soil Science Society of America Journal, 73, 1004-1011. http://dx.doi.org/10.2136/sssaj2008.0216

Shukla, M., Lal, R., \& Ebinger, M. H. (2005). Physical and chemical properties of a mine spoil eight years after reclamation in northeastern Ohio. Soil Science Society of America Journal, 69, 1288-1297. http://dx.doi.org/10.2136/sssaj2004.0221

Soltanpour, P. N., Johnson, G. W., Workman, S. M., Jones, J. B. Jr., \& Miller, R. O. (1996). Inductively coupled plasma emission spectrometer and inductively coupled plasma-mass spectrometry. In D. L. Sparks (Ed.), Methods of soil analysis, Part III, chemical methods (pp. 91-139). Madison, WI: American Society of Agronomy, Crop Science Society of America, Soil Science Society of America.

Spaccini, R., Piccolo, A., Mbagwu, J. S. C., ZenaTeshale, A., \& Igwe, C. A. (2002). Influence of the addition of organic residues on carbohydrates content and structural stability of some highlands soils in Ethiopia. Soil Use \& Management, 18, 404-411. http://dx.doi.org/10.1079/SUM2002152

Thomas, G. W. (1996). Soil pH and soil acidity. In D. L. Sparks (Ed.), Methods of soil analysis, Part III, chemical analysis (pp. 475-489). Madison, WI: Soil Science Society of America, American Society of Agronomy.

Tilman, D., Hill, J., \& Lehman, C. (2006). Carbon-negative biofuels from low-input high-diversity grassland biomass. Science, 314, 1598-1600. http://dx.doi.org/10.1126/science.1133306

Tisdall, J. M., \& Oades, J. M. (1982). Organic matter and water stable aggregates in soils. Journal of Soil Science, 33, 141-163. http://dx.doi.org/10.1111/j.1365-2389.1982.tb01755.x

Torrent, J., \& Barrón, V. (1993). Laboratory measurements of soil color: theory and practice. In J. M. Bigham, E. J. Ciolkosz, \& R. J. Luxmoore (Eds.), Soil color. SSSA Special Publication no. 31 (pp. 21-33). Madison, WI: Soil Science Society of America.

USDA (United States Department of Agriculture) \& NRCS (Natural Resources Conservation Service). (2007). Soil survey of Muskingum Country, Ohio.

USEPA (United States Environmental protection Agency). (1988). Wastes from the combustion of coal by electric utility power plants. USEPA Rep. 530-SW-88-002. Washington DC: USEPA.

USEPA (United States Environmental protection Agency): Office of Water. (2000). Biosolids technology fact sheet: Alkaline stabilization of biosolids. EPA 832-F-00-052. Retrieved from www.epa.gov/region8/water/biosolids/.../BiosolidsTechSheetAlk.pdf.

Ussiri, D. A. N., Lal, R., \& Jacinthe, P. A. (2006). Soil properties and carbon sequestration of afforested pastures in reclaimed minesoils of Ohio. Soil Science Society of America Journal, 70, 1797-1806. http://dx.doi.org/10.2136/sssaj2005.0352

Wallace, B. M., Krzic, M., Forge, T. A., Broersma, K., \& Newman, R. F. (2009). Biosolids increase soil aggregation and protection of soil carbon five years after application on a crested wheatgrass pasture. Journal of Environmental Quality, 38, 291-298. http://dx.doi.org/10.2134/jeq2007.0608

\section{Copyrights}

Copyright for this article is retained by the author(s), with first publication rights granted to the journal.

This is an open-access article distributed under the terms and conditions of the Creative Commons Attribution license (http://creativecommons.org/licenses/by/3.0/). 